\title{
GOING INTO THE AFFORDABLE CARE ACT: MEASURING THE SIZE, STRUCTURE AND PERFORMANCE OF THE INDIVIDUAL AND SMALL GROUP MARKETS FOR HEALTH INSURANCE
}

\author{
Pinar Karaca-Mandic \\ Jean M. Abraham \\ Kosali Simon \\ Roger Feldman \\ Working Paper 19719 \\ http://www.nber.org/papers/w19719 \\ NATIONAL BUREAU OF ECONOMIC RESEARCH \\ 1050 Massachusetts Avenue \\ Cambridge, MA 02138 \\ December 2013
}

This work was supported by the Robert Wood Johnson Foundation's State Health Reform Assistance Network (State Network) grant to the State Health Access Data Assistance Center (SHADAC). The views expressed herein are those of the authors and do not necessarily reflect the views of the National Bureau of Economic Research.

NBER working papers are circulated for discussion and comment purposes. They have not been peerreviewed or been subject to the review by the NBER Board of Directors that accompanies official NBER publications.

(C) 2013 by Pinar Karaca-Mandic, Jean M. Abraham, Kosali Simon, and Roger Feldman. All rights reserved. Short sections of text, not to exceed two paragraphs, may be quoted without explicit permission provided that full credit, including (C) notice, is given to the source. 
Going into the Affordable Care Act: Measuring the Size, Structure and Performance of the Individual and Small Group Markets for Health Insurance

Pinar Karaca-Mandic, Jean M. Abraham, Kosali Simon, and Roger Feldman

NBER Working Paper No. 19719

December 2013

JEL No. I1,I13,I28

\section{ABSTRACT}

The Affordable Care Act (ACA) will dramatically alter health insurance markets and the sources through which individuals obtain coverage. As the ACA is implemented, it is essential to monitor the intended and the unintended consequences of these regulations. To evaluate the changes in health insurance markets linked to the ACA, it is critical to consistently measure the size and structure of health insurance markets, as well as the performance of participating health insurers, prior to and post-ACA. In this paper we discuss challenges of describing the size, structure, and performance of the individual and small group markets. Next, we discuss improvements in data availability starting in 2010 to address some of these concerns. Finally, using data from the National Association of Insurance Commissioners (NAIC), we evaluate insurance market structure and performance during 2010-2012, focusing on enrollment, the number of participating insurers, premiums, claims spending, MLR, and administrative expenses.

Pinar Karaca-Mandic

Division of Health Policy and Management University of Minnesota

420 Delaware Street SE, MMC 729

Minneapolis, MN 55455

and NBER

pkmandic@umn.edu

Jean M. Abraham

Department of Health Policy and Management

University of Minnesota

20 Delaware St SE

MMC 729

Minneapolis, MN 55455

abrah042@umn.edu
Kosali Simon

School of Public and Environmental Affairs

Indiana University

Rm 359

1315 East Tenth Street

Bloomington, IN 47405-1701

and NBER

simonkos@indiana.edu

Roger Feldman

Health Policy and Management

School of Public Health

University of Minnesota

Mayo Mail Code 729

420 Delware Street S.E.

Minneapolis, MN 55455-0392

feldm002@umn.edu 


\title{
Going into the Affordable Care Act: Measuring the Size, Structure and Performance of the Individual and Small Group Markets for Health Insurance
}

\author{
Pinar Karaca-Mandic, University of Minnesota and NBER \\ Jean M. Abraham, University of Minnesota \\ Kosali Simon, Indiana University and NBER \\ Roger Feldman, University of Minnesota
}

Acknowledgements This work was supported by the Robert Wood Johnson Foundation's State Health Reform Assistance Network (State Network) grant to the State Health Access Data Assistance Center (SHADAC).

\section{Introduction}

The Affordable Care Act (ACA) will dramatically alter health insurance markets and the sources through which individuals obtain coverage. All low-income Americans above the poverty line who lack access to affordable employer-sponsored insurance will be eligible for subsidies to purchase individual insurance in state-based Exchanges (or "Marketplaces"). This provision of the ACA will greatly expand the size and importance of the individual market. The Congressional Budget Office projects that approximately $17 \%$ of the non-elderly population will obtain coverage in the individual market by 2016 (Congressional Budget Office, 2012); today that number stands at only 5\%.

Only 35.2\% of private-sector establishments with fewer than 50 employees offered health insurance to their employees in 2012. In contrast, $95.9 \%$ of those with 50 or more employees did so. ${ }^{1}$ Establishment of Small Business Health Options Program (SHOP) exchanges in 2014 will simplify the health insurance shopping experience for small employers (50 or fewer full-time equivalent employees) as

\footnotetext{
${ }^{1}$ http://meps.ahrq.gov/mepsweb/data_stats/summ_tables/insr/national/series_1/2012/tia1a.htm (accessed September 23, 2013) 
well as allow their employees to choose from among options in an 'exchange like' setting, although without access to exchange tax credits. ${ }^{2}$

The ACA also increases regulation of health insurers and health insurance markets, for example, by controlling premium increases through rate review regulation and by regulating insurers' medical loss ratios (MLRs), which broadly represents the proportion of health insurance premium revenues that is paid out in medical claims. Additional ACA provisions require policies to include essential benefits and limit price variance through modified community rating.

The MLR regulations were among the first ACA provisions to be implemented. Beginning in January 2011, insurers in the individual and small group markets must spend at least 80 percent of their premium revenue on medical care and quality improvement activities while insurers in the large group market must have MLRs of at least 85 percent. Insurers must provide annual information on their MLRs to the U.S. Department of Health and Human Services. Those that fail to meet the $80 \%$ and $85 \%$ minimum MLR thresholds for the individual/small group and large group segments must provide equivalent rebates to their policyholders beginning in 2012.

While the MLR regulation monitors the ratio of spending on medical benefits to premiums, another ACA provision, rate review regulation, complements it by controlling premium increases. Under rate review regulation, insurers must document and publicly justify "unreasonable premium increases" when they file advance notice of rates starting with the 2011 plan year. Before the ACA, states had substantial variation in their authority to review rates (Kaiser Family Foundation, 2010). Almost half of the states had "prior approval” rate regulation in which regulators could review the rates ${ }^{3}$ and approve or disapprove proposed changes. In contrast, other states had “file and use” regulations in which insurers had to provide actuarial justification for rate increases, but could proceed with rate increases without state

\footnotetext{
${ }^{2}$ SHOP exchanges will administer the small business health care tax credits, but these are much more limited than the individual subsidies provided through the Exchange. More details on the small business tax credits can be found at http://www.irs.gov/uac/Small-Business-Health-Care-Tax-Credit-for-Small-Employers and http://www.taxpayeradvocate.irs.gov/calculator/SBHCTC.htm

${ }^{3}$ The "rate" is distinct from the "premium". While the premium is the total cost of the policy paid by an individual or group (i.e. family), rate is the "unit cost" of the policy. Rates may vary by number of dependents in a policy, benefit design of the policy, age, gender, previous claims experience, and geographic location.
} 
approval. However, the state reserved the right to intervene if the rates were later found to be “unreasonable.” Only a few states lacked any regulatory authority over rates. States also had different criteria for deeming rates to be reasonable. ${ }^{4}$ States differed in levels of enforcement of their regulations as well as in the strength of their regulatory oversight. While the ACA does not require any changes to the states' existing rate review regulation authority, various states have amended their laws to align them better with the federal law.

As the ACA is implemented, it is essential to monitor the intended and the unintended consequences of these regulations. To evaluate the changes in health insurance markets linked to the ACA, it is critical to consistently measure the size and structure of health insurance markets, as well as the performance of participating health insurers, prior to and post-ACA.

In this paper we discuss challenges of describing the size, structure, and performance of the individual and small group markets. Next, we discuss improvements in data availability starting in 2010 to address some of these concerns. Finally, using data from the National Association of Insurance Commissioners (NAIC), we evaluate insurance market structure and performance during 2010-2012, focusing on enrollment, the number of participating insurers, premiums, claims spending, MLR, and administrative expenses.

\section{The Size of the Individual and Small Group Markets for Health Insurance Individual Market}

Estimates based on the Current Population Survey (CPS) suggest that approximately 5\% of the U.S. population has individually-purchased coverage (Kaiser Family Foundation, 2011, http://kff.org/other/state-indicator/total-population/). However, estimates vary widely across different federal surveys. Abraham, Karaca-Mandic and Boudreaux (2013) estimated the size of the individual market for health insurance during the period just before passage of the ACA. The authors also

\footnotetext{
${ }^{4}$ While most states used medical trends, rate history and MLR in determining whether the rates were "unreasonable", they used different thresholds.
} 
documented strengths and limitations of particular federal surveys and administrative data sources for addressing questions about the individual market. They considered four prominent federal surveys: the National Health Interview Survey (NHIS); the Medical Expenditure Panel Survey Household Component (MEPS-HC); the Annual Social and Economic Supplement to the Current Population Survey (CPS); and the American Community Survey (ACS). They also considered an administrative data source from the National Association of Insurance Commissioners (NAIC).

Abraham et al. (2013) found that federal survey estimates of the individual market vary widely from 9.5 million non-elderly in MEPS to 25 million in the ACS (Table1). Their study suggests three important measurement issues outlined in Table 1. First, surveys differ in how they elicit coverage in the individual market. Rather than asking respondents directly if they are covered by individual health insurance, they ask about “directly purchased” coverage with different purchasing arrangements (e.g. from an insurance company or a group such as a school).Second, surveys vary in differentiating the types of individual policies (e.g. comprehensive coverage, limited benefit, disease-specific, or short-term). In fact, none of the surveys ask whether the health plan includes comprehensive medical and hospital coverage. Even if the surveys asked such questions, individuals may not be aware of the comprehensiveness of their plans unless they are frequent health care users. This is important, because some ACA regulations, such as the MLR regulation and the expansion of the individual market under Exchanges, apply only to comprehensive coverage. ${ }^{5}$

Abraham et al. (2013) highlighted a third point: surveys differ in the reference period of the insurance questions (e.g. coverage at the interview date versus coverage any time during the previous calendar year). While "point-in-time” surveys that ask about coverage at the interview date avoid recall bias, they miss individuals who held coverage during the year but dropped it prior to the interview date. For example, the CPS asks if a respondent had individual coverage at any time during the previous

\footnotetext{
${ }^{5}$ https://www.federalregister.gov/articles/2012/05/16/2012-11753/medical-loss-ratio-requirements-under-the-patientprotection-and-affordable-care-act. Also see Congressional Research Service (September 18,2012) http://www.fas.org/sgp/crs/misc/R42735.pdf
} 
calendar year. This framing has the greatest potential for recall bias (Klerman et al. 2009). Moreover, it is not possible to know whether a respondent held individual coverage at the time of the interview, part of the year, or throughout the entire year. These are important measurement issues, especially because enrollment patterns in the individual market are typically dynamic throughout the year. Many who buy individual policies use it to bridge short-term coverage gaps (e.g. transitions from job-to-job or school-tojob and retirement-to-Medicare eligibility).

To partially reconcile large differences across the surveys, Cantor et al. (2007) and Mach and O’Hara (2011) defined a coverage hierarchy, whereby individuals who report multiple coverage types are assigned to only one category. The hierarchy prioritizes coverage types in the following order: public, employer-sponsored coverage, direct purchase, and uninsured. Their basic premise is that a substantial portion of people who report both individual market and another coverage types on these surveys really have one comprehensive policy. For example, an individual could be covered primarily through an employer-sponsored policy, but also have a single-service dental plan and thus report both employer sponsored insurance and the direct purchase option. This adjustment (also presented in Table 1) to redefine coverage types into just one main type by using a hierarchy results in a smaller estimate of the size of individual market and a tighter alignment across different federal surveys (8,215,358 in MEPS and 16,635,033 in ACS).

\section{Small Group Market}

In contrast to the individual market, not all household surveys discussed above can measure coverage obtained through the small employer group market because most household surveys do not ask working individuals about the size of their employer. Several studies have used the size of the worker’s establishment in conjunction with whether the establishment has more than one location as a proxy for firm size (Abraham, DeLeire and Royalty, 2009; Monheit and Schone, 2004). However, this approach would classify a large-firm employee working in an establishment with few employees as a small-firm employee. Even if the survey asks respondents for firm size, it is unclear whether workers can accurately 
assess this, especially when the firm has multiple locations. Nationally representative employer surveys such as the MEPS-Insurance Component (MEPS-IC), in contrast, can estimate the size of the small group market more accurately than household surveys.

The MEPS-IC samples public and private-sector establishments, collecting information on their health insurance offerings and characteristics of the workers and workplace. A firm could have one or more establishments, but each surveyed establishment provides information on the total number of employees across all establishments, which allows an inference of firm size; firm size is also checked against administrative sources. National and state-level estimates of insurance coverage by year are publicly available from the MEPS-IC. ${ }^{6}$

Using several statistics reported in these tables, we estimated the number of employees with health insurance in firms with fewer than 50 employees (Table 2). In 2009, approximately 10,587,185 small-firm employees had employer-sponsored health insurance (9,359,072 through fully-insured plans and 1,228,113 through self-insured plans). These numbers do not include dependents of the primary insurance holders. Previous research estimated an average of one dependent per employee in small firms (KaracaMandic, Abraham, and Phelps, 2011), which suggests a total of 21,174,370 enrollees in the small group market and 18,718,144 in fully-insured plans. Estimates of small group insurance also come from Kaiser HRET/surveys, although their sample size of small employers is typically limited and the micro-data are not easily accessed by researchers.

Thus, prior estimates of the size of the individual market have relied on household surveys and provide a range of sizes due to the inherently difficult nature of discerning individual level coverage. In contrast, estimates of the small group market come from employer surveys linked to administrative data and are more reliable. The challenges in estimating the size of these markets spill over to difficulties in defining the target populations of ACA insurance market policies. Having discussed these challenges, we

\footnotetext{
${ }^{6}$ Summary statistics at http://meps.ahrq.gov/mepsweb/data_stats/quick_tables.jsp\#insurance contain publicly released data. Researchers wishing to use the MEPS-IC must obtain approval from the Census Bureau and the Internal Revenue Service and must access the data at a Census Research Data Center.
} 
turn our attention to measures of the structure of these markets, including the number of participating insurers, market shares, and concentration.

\section{The Structure of the Individual and Small Group Markets for Health Insurance}

Assessing the structure of the individual and small group markets has been hampered by lack of data on these insurers. Until 2011, the National Association of Insurance Commissioners (NAIC) was the only national administrative data source available to identify insurers operating in the individual and group markets. NAIC is the organization of insurance regulators from the 50 states, the District of Columbia, and the five U.S. territories. The NAIC data represent a compilation of health insurer filings of Annual Statements to the Insurance Department of each state in which they sell their products. Prior to 2010, NAIC data on detailed state-level insurer level/aggregated information on premiums earned and written, amounts paid and incurred for provision of health care services, and member months of coverage by "line of business" came from the Exhibit of Premiums, Enrollment, and Utilization, also known as the “State Page.” Lines of business include comprehensive individual coverage, comprehensive group coverage, Medicare supplements, vision, dental, FEHBP, Medicare, and Medicaid. However, the NAIC data have several major limitations. First, the vast majority of insurers operating in California are regulated by the California Department of Managed Health Care and do not file with the NAIC.

Second, as already alluded to, one cannot easily use pre-2010 NAIC data to study health insurance industry structure. One difficulty in using the NAIC data prior to 2010 relates to the classification of insurers into categories based on their primary business. Insurers with more than $95 \%$ of their business in health insurance were required to file as health insurers, and they filled out "exhibits" (essentially questionnaires) in the Health Blanks (including the "State Page”). However, life, fraternal, and property/casualty insurers that also write health insurance policies (but for whom health insurance is $95 \%$ or less of their business) did not file the same Health Blanks. As a result, until 2010, such organizations were not required to file information on enrollment, premiums, or claims specific to comprehensive 
(hospital and medical) coverage in individual and group market segments under the State Page. ${ }^{7}$ Lack of such information made it impossible to assess the number of insurers selling comprehensive medical insurance in the individual market and the group market using the NAIC data. Major life insurers could potentially have a large market share in these market segments, yet it was not possible to gauge the extent of their presence and their share of total premiums in any state and year. While each insurance regulator's website typically lists the insurers operating in that state, one cannot easily obtain detailed information about their market shares.

Another problem with the NAIC data prior to 2010 is that insurer filings did not distinguish whether the insurer operated in the small group versus the large group market. Similarly, enrollment, premiums, claims and other financial information was filed under the "group market” business line segment rather than distinguishing between the small and large group markets.

Following passage of the ACA, NAIC has actively collaborated with the U.S. Department of Health and Human Services (HHS) to design standard measures, definitions and methodologies related to the regulatory targets such as the MLR. ${ }^{8}$ Starting in the 2010 filing year, insurers file new supplementary information with the NAIC. Karaca-Mandic and Abraham (2013) summarized the features of NAIC’s new reporting exhibit titled the Supplemental Health Care Exhibit (SHCE).This exhibit is similar to the earlier State Pages, but it is also filed by life, fraternal, and property/casualty insurers (starting with filing year of 2010) that sell health insurance policies in the individual, small, and large group (fully-insured) markets. SHCE includes detailed information on the number of covered lives, number of policies, member months, health premiums earned, federal taxes, state insurance, premium and other taxes, incurred claims, incurred expenses for improving health care quality as well as detailed information on claims adjustment expenses, general and administrative expenses. In the SHCE, insurers separately report

\footnotetext{
${ }^{7}$ See Abraham and Karaca-Mandic (2011) and Karaca-Mandic and Abraham (2013) and Karaca-Mandic, Abraham and Simon (2013) for more detail on the comprehensiveness of the NAIC data. Dafny, Dranove et al (2011) also discuss the NAIC data. ${ }^{8}$ For example, see the list of NAIC responsibilities as of April 2010 at: http://www.naic.org/documents/index_health_reform_naic_tasks.pdf
} 
on comprehensive medical coverage in the individual, small group and large group markets, as well as on mini-med plans (with annual limits of \$250,000 per person per year), for each state in which they operate.

A new independent source of data on insurers is the MLR regulatory filings collected by the U.S. Department of Health and Human Services’ Center for Consumer Information and Oversight (CCIIO) starting in 2011. There is some uncertainty regarding what fraction of insurers report data. A recent Kaiser study (see below) used the 2011 CCIIO regulatory filings and found estimates of individual and small group market size very similar to the NAIC. Since these data start in 2011, it is not possible to use them for pre-post comparisons.

\section{Insurance Market Structure Prior to 2010}

Although it is not possible to distinguish small and large group insurers prior to 2010, the NAIC State Pages can be used to study individual market insurers (subject to the caveat that the State Pages do not include data on life insurers that also sold health insurance). Using these data, Abraham and KaracaMandic (2011) presented snapshots of the number of active health insurers and estimated enrollment in the individual market from 2002-2009 by state. In 2009, five states (Florida, New York, Michigan, Pennsylvania, and Ohio) each had at least 15 insurers. Ten states (Alabama, Mississippi, Vermont, Alaska, Delaware, Hawaii, North Dakota, New Hampshire, Rhode Island, and Wyoming) had three or fewer health insurers. Most states experienced an increase in the number of health insurers and modest enrollment growth from 2002 to 2009. However, the authors acknowledged their estimates do not include life insurers also selling health insurance, nor do they include insurers in California.

Karaca-Mandic, Abraham and Simon (2013) also used the NAIC data to evaluate health insurance market structure and its relation to medical loss ratios in the individual market from to 2001 to 2009. In the 2011 U.S. Department of Health and Human Services’ interim final rule, insurers with less than 1,000 member years in a state are deemed to have "non-credible” MLRs for regulatory enforcement and are exempt from the minimum MLR requirements. The authors identified 11 states in 2009 with only one credible health insurer serving the individual market. Because "life insurers" do not file data with the 
NAIC, additional work is necessary to confirm that this really indicates these states had monopoly-like markets. In additional analysis of these 11 states using data from the state commissioners' web pages as well as the NAIC data from SHCE in 2010 and 2011, they confirmed that the credible health insurer identified was in fact the dominant insurer in the state (in terms of market share). However, the authors found that "life insurers" in all these states also sold health insurance to individuals. The largest life insurer had only 4 to-8\% of the total premium revenue in most of these markets, but there were a few states in which the largest life insurer accounted for 10 to $16 \%$ of individual health insurance premiums.

\section{Insurance Market Structure in 2010 and After}

Starting with the 2010 filing year, the SHCE provides a unique opportunity to construct a complete picture of both the individual and the small group health insurance markets. Because the exhibit is filed by life, fraternal, and property/casualty insurers in addition to health insurers, it is now possible to construct counts of all insurance carriers selling comprehensive health insurance. The reported number of policies, covered lives, member months and premiums earned can be used to conduct a more complete market share analysis because it is now possible to include the market shares of the non-health insurers. Similarly, given that information is now available on all market participants, one can construct measures of market structure (e.g. the Herfindahl index) by states. In addition, the fully-insured small and large group markets can be separately identified, and thus the SHCE presents the first opportunity to examine the small group market.

In this paper, we used the 2010-2012 SHCE to examine the numbers of insurers in the individual and small group markets by state, lines of business (health insurance or life insurance) ${ }^{9}$, and whether they are credible or not. In 2010 and 2011, credible firms were defined as those having at least 1,000 member years. Credible firms with fewer than 75,000 member years were considered “partially credible” by DHSS, while those with at least 75,000 member years were considered “fully credible”. Starting in 2012,

\footnotetext{
${ }^{9}$ Property/Casualty and Fraternal insurers are extremely small players in health insurance markets. For example, they account for less than one percent of premium revenues for individual market comprehensive major medical policies (Abraham and Karaca-Mandic, 2011).
} 
“credible experience” is defined in a cumulative manner. If an insurer has fewer than 75,000 member years in 2012 in a given state and segment (e.g. individual, small group), its MLR is calculated using data reported for both the 2011 and 2012 MLR reporting years (Department of Health and Human Services, December 1, 2010, MLR Interim Rule). Therefore, even though an insurer may be "non-credible” (fewer than 1,000 member years) for the 2012 reporting year alone, it is not necessarily exempt from MLR regulation if it has at least 1,000 combined member years for 2011 and 2012. For 2012, we thus define credible insurers as those with at least 1,000 member years combined for 2011 and 2012.

Table 3 presents the numbers of credible and non-credible insurers in 2010 and 2012 by state in the individual market, distinguishing health and life insurers. Table 4 presents the breakdown of enrollment by credible versus non-credible and by health and life insurers in the state in 2010 and 2012. Tables 5 and 6 repeat the same exercises for the small group market.

Table 3 shows that life insurers participate actively in the individual market. In 2010, states had, on average, four credible health insurers, three non-credible health insurers, seven credible life insurers, and 31 non-credible life insurers. The 2012 data reveal similar patterns, although slightly smaller numbers of credible and non-credible life insurers (eight and 19 on average, respectively). States with only one credible health insurer in 2010 (AK, DE, MS, MD, NH, RI, WY) had at least 2 to 4 credible life insurers, except for RI and ND (only one credible life insurer). The majority of states with only two credible health insurers in 2010 (AL, ID, IA, IN, KS, NC, NE, NV, OK, TN) had at least five credible life insurers. Credible life insurers were largely absent from the remaining states with only two credible health insurers in 2010 (two in KY, one in ME, and none in HI and VT). Table 4 shows that credible health insurers comprised $70 \%$ of the individual market in 2010, on average, followed by credible life insurers (26\%) and non-credible life insurers (4\%). Overall, non-credible health insurers had a negligible market share (average of 0.01\%). These figures remained stable in 2012.

Relative to the individual market, the small group market had more credible health insurers in 2012 (on average seven per state), slightly fewer non-credible health insurers (on average two) and 
substantially fewer credible and non-credible life insurers (on average four and five, respectively) (Table 5). Credible health insurers comprised about $80 \%$ of the small group market by market share. Credible life insurers comprised the remaining fraction of the market (about 20\%), leaving non-credible health and life insures with a negligible market share (Table 6).

In Table 7, we describe entry and exit of insurers as well as transitions from credible to noncredible status and vice-versa between 2010 and 2012. Of the 534 credible life and health insurers in the individual market in 2010, 455 remained credible in 2011, of which 437 remained credible also in 2012. Fifty-seven were not credible in 2011, and 22 exited the market in 2011.

Transition from non-credible to credible status was uncommon. Among 1,727 non-credible insurers in 2010, 34 became credible and 1,157 remained non-credible in 2011. Of these 1,157 noncredible insurers, 51 became credible, 815 remained non-credible, and 219 exited the market in 2012.The exit rate of these non-credible insurers was high, with 536 of the 1,727 non-credible insurers from 2010 exiting in 2011.

In the small group market, most credible insurers in 2010 were credible also in 2011 and 2012 (470 of 585). Many non-credible insurers in 2010 remained non-credible in 2011 and 2012 (274 out of 500). As in the individual market, a large fraction of the non-credible insurers from 2010 exited in 2011 (100 of 500).

To investigate market structure further, we computed the Herfindahl-Hirschman index (HHI) for the individual market (Figure 1 for 2010, Figure 2 for 2012) and the small group market (Figure 3 for 2010, Figure 4 for 2012). We present a 4-category breakdown of HHI by state using the DOJ/FTC Horizontal Merger Guidelines: $<1,500$ (unconcentrated); 1,500-2,499 (moderately concentrated); 2,5004,999 (highly concentrated); 5,000 and above (highly concentrated). Fourteen states had an individual market $\mathrm{HHI}$ less than 2,500 in both years. Similarly, in the small group market, the number of states with HHI less than 2,500 remained stable (18 in 2010, and 20 in 2012). Several states had HHIs exceeding 5,000 in 2012 (individual market: AL, AR, IA, KY, NC, ND, NE, NH, NM, RI, SD, VA, VT; small group 
market: AK, AL, KY, MS, ND, RI) suggesting that the individual market is highly concentrated in many states. The average HHI in the individual market across all states increased from 2010 to 2012 (3,680 and 3,920 respectively). The corresponding median and the $90^{\text {th }}$ percentiles of the HHI also increased during this time period (median: from 3,300 to 3,266; 90th percentile: from 6,368 to 6,958).

These NAIC data describing market structure are consistent with findings from the CCIIO Medical Loss Ratio Annual Reporting Data (available only after 2011) prepared by the Centers for Medicare and Medicaid Services (CMS). In an analysis of the 2011 data, researchers from the Kaiser Family Foundation reported market shares of the dominant, second-largest and third-largest insurers by state (Kaiser State Health Facts, available online ${ }^{10}$ ). For example, in our analysis of the NAIC data, AL is one of the most concentrated individual markets (HHI of 8,313 in 2012). Kaiser’s analysis shows that the dominant insurer in the individual market of AL (Blue Cross and Blue Shield of Alabama) had 90\% market share. In another high HHI state in our analysis, NC (HHI of 7,312 in 2012), Blue Cross Blue Shield of NC was the dominant insurer with 83\% market share in Kaiser's analysis. Similarly, in RI (HHI of 9,072 in 2012), Blue Cross \& Blue Shield of Rhode Island had 95\% market share. Kaiser's analysis of the small group market is also comparable with our analysis based on NAIC data. In our analysis, the states with highest small-group market HHI were AL (9,429 in 2012) and MS (7,639 in 2012). Kaiser’s analysis shows that the largest insurer in AL (Blue Cross and Blue Shield of Alabama) had 97\% market share. In MS, Mississippi Insurance Group was the dominant carrier in MS with 73\% market share. Overall, the small group market was less concentrated relative to the individual market. Average HHI across all states were 3,252 in 2010 and 3,353 in 2012.

\section{The Performance of Insurers in the Individual and Small Group Markets for Health Insurance}

\footnotetext{
${ }^{10}$ http://kff.org/other/state-indicator/individual-insurance-market-competition/ (accessed 9/23/ 2013)
} and http://kff.org/other/state-indicator/small-group-insurance-market-competition/ (accessed 9/23/2013) 
Many empirical studies have investigated factors - primarily market structure and regulations that explain variation in health insurance premiums. A smaller body of recent research has focused on estimating the size of insurers’ loading fees and/or medical loss ratios. The ACA medical loss ratio regulations implemented in 2011 have created heightened awareness of the latter. Other measures of insurer performance less commonly examined include insurer administrative expenses and operating margins.

\section{Evaluating Insurer Performance Prior to 2010}

Abraham and Karaca-Mandic (2011) analyzed the potential impact of the ACA's regulation of insurers' medical loss ratios (MLR, the percentage of premium that goes to clinical services). Using the NAIC State Pages data from 2002, 2005 and 2009, they documented large variation in individual market MLRs by state, with enrollment-weighted average MLRs ranging from 0.629 in New Hampshire to more than 1.0 in Alabama, Massachusetts, Michigan, and North Dakota in 2009. Additionally, they estimated that $29 \%$ of insurer-state observations with $32 \%$ of individual market enrollment would have MLRs (based on the historical definition) below the $80 \%$ minimum threshold imposed by the ACA regulations.

Karaca-Mandic, Abraham and Simon (2013) also used NAIC data from 2001 through 2009 to compare the MLR and the percentage of premiums spent on administrative expenses in more and less competitive markets, measured by the number of insurers. They found that markets with only one credible insurer (least 1,000 member-years of enrollment) have lower MLRs, controlling for insurer characteristics, health care provider market structure and other market attributes, and population-level demographics and health status.

A concern with viewing MLR regulations as limiting insurer market power is that the MLR is only one component of the price-cost margin; the other component is the share of premiums spent on administrative costs. Therefore, insurers could respond to the MLR regulation by altering administrative costs in ways that leave the price-cost margin unchanged. For example, insurers could reduce their efforts to manage utilization, leading to lower administrative expenses, higher claims payments, and higher 
MLRs. While some reduction in utilization management may be desirable for improving access to efficient health care (e.g., through lower levels of denials or pre-approvals), this reduction could also lead to increased claims for low-value medical care. Karaca-Mandic, Abraham and Simon (2013) found no evidence that insurers' administrative expenses as a percentage of premiums are related to insurance market structure. Thus, their results are largely consistent with the suggestion that health insurance regulators can use MLRs to measure market power in the individual health insurance market, but with notable caveats relating to measurement issues, limited ability to capture product and firm heterogeneity that can influence differences in price-cost margins, and other potential unintended consequences of the regulation.

Most studies of the small group market focus on state regulations in the 1990s and their effect on premiums (Buchmueller and DiNardo, 2002; Marquis and Long, 2002; Monheit and Schone, 2004, Davidoff, Blumberg, and Nichols, 2005; Simon, 2005). Karaca-Mandic, Feldman, and Graven (2013) recently investigated the effects of competition in the market for insurance agents and brokers on premiums for small employers (50 or fewer employees). Using the Medical Expenditure Panel Survey Insurance Component and data from the National Association of Health Underwriters, they found that premiums of policies offered by small employers are lower in markets with stronger competition among insurance agents and brokers.

A less examined performance measure is the health insurance loading fee $(L)$ that represents the portion of a premium not related to medical care - largely administrative costs. The loading fee typically is modeled as a multiplier to expected claims:

$$
\text { prem }=(1+L) \text { claims }
$$

For example, if premium is $\$ 125$, and expected claims are $\$ 100$, the loading fee is 0.25 or $25 \%$. The loading fee is closely rated to the MLR. Prior to passage of federal health reform, the MLR was defined as the ratio of expected claims paid by the insurer to the premium. Expressing the loading fee as a multiplier of expected claims, the MLR can be written as: 


$$
M L R=1 /(1+L)
$$

In this framework, the loading fee captures an insurer’s costs for general administration, underwriting, marketing, broker commissions, medical management and claims adjudication, as well as any profits or net income for a non-profit insurer.

The most commonly reported loading fee estimates by firm size date back more than two decades, when the Hay/ Huggins Company prepared an actuarial study for the U.S. Congress House Committee on Education and Labor in 1988. These estimates reflected the underwriting practices of major insurers and suggested loading fees of about 40\% for the smallest firms (1-4 employees), 25\% for those slightly larger (20-49 employees), and 18\% for those with 50-99 employees. Hay/Huggins also reported that loading fees decline to $16 \%$ for employers with $100-499$ employees and $12 \%$ for those with up to 2,500 employees. These estimates from the 1980s are still cited frequently in the literature, including current health economics and health insurance texts (Phelps, 2010).

Using data from the confidential MEPS Household Component-Insurance Component Linked File, Karaca-Mandic, Abraham, and Phelps (2011) recently generated new estimates of loading fees and how they differ across the firm size distribution. They found that firms of up to 100 employees face similar loading fees of approximately 34\%. Loads decline with firm size and are estimated to be $15 \%$ for firms with between 101 and 10,000 employees and 4\% for firms with more than 10,000 workers.

\section{Insurer Performance in 2010 and After}

Starting in the 2010 filing year, the SHCE includes line items for insurers to compute each component of the MLR as defined by the regulation. The SHCE also has a line item for the MLR. In comparison with the period before 2010, the ACA regulations made several changes to the historical definition of the MLR (the ratio of claims to premiums). First, the ACA classifies insurers' expenses for certain quality improvement activities as “clinical benefits” that can be counted similarly as medical claims. Certain activities for fraud and abuse detection and recovery can be included in the numerator of 
the MLR. Second, federal and state taxes, licensing and regulatory fees are deducted from premiums earned in the denominator.

Using data from the SHCE, several studies have examined insurer filings for reporting years of 2010 (considered as a pre-MLR regulation year) and 2011. The General Accounting Office (2011) analyzed insurers’ MLRs in the individual and group markets. Using 2010 data and the new ACA standards described above, GAO found wide variation in MLRs in the individual market, with only 43\% of credible insurers and $48 \%$ of covered lives at or above the 2011 standard. These percentages were notably higher for the small and large group markets. Hall and McCue (2012), examining the NAIC’s 2010 data, estimated that rebates paid to consumers would have reached almost \$2 billion (\$1 billion in the individual market, $\$ 0.5$ billion in the small group, and \$0.5 billion in the large group market) if the MLR regulation had been implemented in 2010.

However, it is important to note that measurement of MLR in the SHCE does not exactly match the MLR used by the HHS to determine rebates. In fact, the MLR reported in the SHCE is labeled as the “preliminary MLR.” Several adjustments are needed to properly calculate MLR rebates. The first is a “credibility” adjustment to reflect that insurers with smaller enrollment face more variable claims and premiums, and thus should be given additional room to meet the MLR threshold. Under formulae published in the Interim Final Rule of the regulation, insurers with more than 1,000 but fewer than 75,000 member-years (known as partially-credible insurers) receive a credibility adjustment of up to $8.3 \%$ to their preliminary MLR on a sliding scale. Insurers with 75,000 or more member-years (fully credible) do not receive any credibility adjustment. Using the member-years reported in the SHCE, it is possible to calculate the credibility adjustment.

A second adjustment allows insurers that sell high deductible policies to increase the MLR. The rationale for this adjustment is that administrative cost is generally a disproportionately higher share of the premiums in high deductible policies because the deductible reduces claims costs and premiums but 
not administrative costs. Because the SHCE does not include benefit design information, it is not possible to calculate this adjustment with only the SHCE data.

Third, HHS’s rebate calculations allow claims paid through March of the following year to be included in the numerator of the MLR. Because the SHCE is for the reporting year only, it is not possible to make this adjustment. ${ }^{11}$

Finally, starting with the 2012 filing year, the SHCE calculation of the MLR becomes more complex because the rebate calculation requires the MLR experience of partially credible insurers to be aggregated across several years. For the 2012 reporting year, MLR for these insurers has to be calculated combining 2011 and 2012 data (which we detail below). ${ }^{12}$ Similarly, the credibility adjustment for 2012 is calculated by aggregating member years over 2011 and 2012.

Several recent studies have used 2010 and 2011 SHCE filings to evaluate the early impact of the medical loss ratio regulation. McCue and Hall (December 2012) examined changes in administrative costs and profit margins. They found reductions of about \$209 million in administrative costs in the individual market and \$190 million in the small group market. The authors also documented reductions in profits in the individual market of about \$351 million, but increases in profits in the small group market of about \$226 million. While the average MLR increased from 80.8\% to 84.1\% in the individual market, it stayed about the same $(83.6 \%)$ in the small group market.

In a follow-up study, McCue, Hall and Liu (2013) distinguished between for-profit and non-profit insurers and found that reductions in administrative costs and operating margins were primarily driven by for-profit insurers in the individual market. Non-profit insurers already had high MLRs in 2010 relative to for-profit insurers (88.1\% vs. 71.8\%). In the small group market, the percentage of premiums spent on administrative costs declined more among for-profit firms (from 19.4\% in 2010 to 18.7\% among forprofits, from $12 \$$ to $11.9 \%$ among non-profits). Surprisingly, however, operating margins (defined as the

\footnotetext{
${ }^{11}$ http://www.naic.org/documents/committees_e_health_reform_solvency_impact_exposure_related_doc_shce_preliminary_ml r_cautionary_statement.pdf

${ }^{12}$ Beginning in the 2013 reporting year, information from two years prior to the MLR reporting year will be used
} 
percentage of premiums not spent on clinical services or administrative costs) increased slightly from $1.6 \%$ to $2.8 \%$ among non-profits with no significant change among for-profits.

Abraham, Karaca-Mandic and Simon (2013) also examined the 2010 and 2011 SHCE filings to analyze the early responses of individual and small group market insurers to the MLR regulation. Controlling for various factors - insurers’ ownership type and HMO status, insurance market competition, and existing state laws - they expected to find heterogeneous responses by insurers’ baseline characteristics. They found that several factors were significantly related to insurers' MLRs. Individual market insurers with more enrollments in other market segments have lower MLRs, on average, as do forprofit organizations (2.25 percentage points lower). In contrast, HMOs have MLRs that are 4.58 percentage points higher on average, which may reflect higher actuarial value plans. In the small group market, an insurer's overall enrollment across all states and segments is inversely related to its MLR, but the magnitude is small. Additionally, small group insurers that operate in more concentrated markets, measured by the Herfindahl Hirschman index, have significantly lower MLRs. In contrast, insurers that operate in states with existing MLR regulations have higher MLRs.

In terms of early responses to the MLR regulation, the authors found that individual market insurers with 2010 MLRs that are more than 10 percentage points under the $80 \%$ threshold experienced a 10.94 percentage point increase in MLR from 2010 to 2011 (controlling for the influence of other factors), while those within five points under the threshold experienced only a 2.91 percentage point increase in MLR. Individual market insurers with MLRs more than 10 points above the threshold in 2010 reported a decrease, on average, relative to insurers that were only slightly above the $80 \%$ threshold. A similar pattern of changes in insurers’ MLRs occurred in the small group market.

The Kaiser Family Foundation (April 2012) used data from SHCE filings for 2011 to project rebates of \$426 million, \$377 million and \$541 million in the individual, small group and large group markets respectively. In 2012 consumers actually received about \$1.1 billion in rebates for the 2011 reporting year (\$394 million in the individual market, \$321 million in the small group market, and \$386 
million in the large group market). ${ }^{13}$ The similarity in projected rebates using the 2011 SHCE filings and actual rebates reported by CMS is encouraging in terms of the ability to use NAIC data to study insurance market performance.

Cox, Claxton and Levitt (2013) used the SHCE data for 2010-2012 filings of “preliminary MLRs” and projected that rebates for the 2012 reporting year would be about half the \$1.1 billion received for the previous year. The CMS reported in August 2013 that rebates for the 2012 reporting year were \$193 million in the individual market, \$203 million in the small group market, and \$109 million in the large group market, again verifying the credibility of MLRs reported in the SHCE. ${ }^{14}$

In this paper, we present the first estimates in key insurer performance measures from the 2012 SCHE filings. In Figures 5 and 6, we estimate changes in premiums earned and claims incurred per member year in the individual and small group markets in 2010 and 2012. These amounts are inflated to reflect 2012 dollars. On average, premiums per member year increased from \$2,786 in 2010 to \$3,124 in 2012, and claims per member year increased from \$2,154 in 2010 to \$2,735 in 2012 in the individual market. Both premiums are claims per member year were remarkably stable in the small group market.

In Figures 7 and 8, we decompose the premiums spent for clinical services (i.e. the preliminary MLR), administrative costs and the operating margin (residual from clinical services and administrative costs) in the individual and small group markets. While the operating margin declined steadily over the time period in the individual market (from 6\% in 2010 to 1\% in 2012), it was stable in the small group market (around 5-6\%). Administrative costs as a percentage of the premiums also declined steadily in the individual market (19\% in 2010, 16\% in 2011, and 14\% in 2012), and declined slightly in the small group market (13\% in 2010, 12\% in 2011, and 11\% in 2012).

Next, we present estimates of MLRs in the two markets from 2010 through 2012. As discussed above, calculation of rebates using the preliminary MLR reported in SCHE is complicated. To calculate

\footnotetext{
${ }^{13}$ http://www.hhs.gov/news/press/2012pres/09/20120911a.html (accessed October 1, 2013). McCue and Hall (December 2012) also report the rebates that CMS announced.

${ }^{14}$ http://www.cms.gov/CCIIO/Resources/Data-Resources/Downloads/2012-mlr-rebates-by-state-and-market.pdf (accessed October 1, 2013)
} 
rebates, HHS adjusts the MLRs based on credibility, plan design (i.e. deductibles), and claims paid through March of the following year. Moreover, for the 2012 reporting year, insurer experience was aggregated over 2011 and 2012 reporting years if the insurer had fewer than 75,000 member years (partially credible) in the state and the segment (individual, small group or large group market) in $2012 .{ }^{15}$ This means that both the numerator and the denominator of the MLR formula must be aggregated over the two years before taking their ratio. Moreover, insurers can include rebates paid in the previous year in the numerator to avoid double counting (MLR Interim Final Rule). An insurer’s credibility and the subsequent credibility adjustment to MLR are also based on its aggregated member years in 2011 and 2012.

We were able to conduct the aggregation exercise for the 2012 reporting year. We also made the credibility adjustment for the size of the insurer from member years reported in the SCHE. However, we could not adjust for benefit design or claims payments up to the first quarter of the following year.

Table 8 presents our estimates of MLR for fully credible insurers with at least 75,000 member years in the state-segment. The unique number of such insurers and the number of insurer-state observations are very similar, suggesting that such insurers are typically local, operating in just one state. The average MLR increased from 80.39\% (95\% CI 76.76\%-84.03\%) in 2010 to 85.38\% (95\% CI 83.21\%-87.54\%) in 2012 in the individual market, with 89\% of the insurers meeting the MLR threshold of 80\%. Changes in MLRs in the small group market are smaller (83.56\% in 2010, and 84.88\% in 2012). Median MLRs in 2012 are 83.55\% and 83.7\% in the individual and small group markets respectively. Table 9 reports summary statistics based on preliminary MLRs (with no adjustment), as well as MLRs adjusted for aggregation and credibility for the partially credible insurers. The number of partially credible insurers in either the individual or the small group market is noticeably higher than the number fully credible insurers reported in Table 8. In 2012, 169 unique insurers represented 409 insurer-state

\footnotetext{
15 Starting 2013, the experience for partially credible insurers is aggregated over three years (for example over 2011, 2012 and 2013 for the reporting year of 2013).
} 
observations in the individual market, and 244 unique insurers represented 437 insurer-state observations in the small group market. Not surprisingly, the percentage of insurers meeting the 80\% MLR threshold increased over time in both markets. Based on preliminary MLRs reported in SHCE (with no adjustment) for $2012,60 \%$ of the insurers in the individual market, and $68 \%$ of those in the small group meet the MLR threshold. However, when adjusted for the aggregation of 2012 reporting year with the 2011 reporting year, these numbers decline to $51 \%$ and $67 \%$ respectively suggesting that aggregation rule penalizes insurers if they have low MLRs in 2011. After incorporating the credibility adjustment to the aggregation adjustment, the percentage of insurers meeting the MLR threshold in 2012 increases (61\% in the individual market, $76 \%$ in the small group market). In terms of the average MLR in 2012, the aggregation adjustment moved the average MLR from 85.39\% (preliminary) to $83.82 \%$, but the additional credibility adjustment moved it up about three percentage points to $87 \%$ in the individual market. The adjustments moved the average MLR similarly in the small group market in 2012 from 84.14\% (preliminary) to 83.24\% (aggregation adjustment) and to 85.58\% (aggregation and credibility adjustments).

\section{Other Measurement Issues}

The SHCE was developed with the primary purpose of measuring relevant components of insurers’ MLRs (claims, premiums, quality improvement, and expenses for detection of fraud and abuse) as well as tracking their administrative expenses (e.g., claims adjudication, total general and administrative expenses including sales and brokers fees), and other financial aspects of the health insurers. Because the MLR regulation currently applies to individual and group markets only, the SCHE lacks information on other business segments represented in the State Pages (Medicare supplement, Dental, Vision, Federal Employees Health Benefit Plan, Title XVIII Medicare and Title XIX Medicaid).

Another limitation of the SHCE is that it lacks information on health services utilization encounters such as physician and non-physician ambulatory encounters and hospital inpatient days incurred, which is included in the Health State Pages. While one could use the SHCE together with the 
Health State Pages to obtain a more complete picture, life insurers and other non-health insurers selling health insurance still do not file the Health State Pages.

Finally, the figures reported in the SHCE do not allow for calculating exact rebates as discussed above. While it is possible to make credibility adjustments for partially credible insurers, neither the SHCE nor the State Pages includes information on the share of high-deductible plans or premiums. As another adjustment we did not discuss earlier, an insurer with 50\% or more of earned premiums attributed to newly issued policies can be excluded from the MLR reports because they are likely to have lower claims. The SCHE and the State Pages do not include information on the share of newly issued policies.

As the ACA changes of 2014 begin to be implemented, it would of course be valuable for researchers to track consumers’ and insurers’ participation in health insurance exchanges. For example, Federal household surveys could include questions on the scope of the insurance policy (e.g. comprehensive or limited benefit), premiums and subsidies for the policy, as well as whether the policy was purchased in the exchange. Similarly, employer-based surveys such as MEPS-IC could incorporate additional questions to measure small employers' participation in SHOP exchanges (for example, whether they participated, the metal levels, and the premiums of the policies). NAIC could also request information that separates each insurer's business separately in and out of the exchange in each state both for the individual and small group markets.

\section{Conclusion}

We provided a synthesis of the research available to measure and evaluate the size, structure and performance of the individual and small group markets. We discussed the availability and use of different data sets in measuring these concepts and we highlighted important measurement problems and possible solutions to consider when assessing the performance of health insurance markets as the ACA is fully implemented. Finally, we presented new estimates from 2012 using the NAIC SCHE filings.

Even after coverage hierarchies are imposed, Federal household surveys give widely different estimates of how many individuals were covered in the individual market prior to the ACA. While it is 
premature to know precisely how the individual market will evolve given the introduction of Exchanges and additional regulatory structures created by ACA, we will presumably have better information on enrollment starting in 2014. Nevertheless, it may be difficult to track changes in enrollment and to conduct studies based on a pre/post-ACA design using the Federal household surveys because of the limitations in properly estimating the size of the individual market at the baseline. Unlike in the individual market, we have better estimates of the small group market enrollment from the MEPS-IC.

The NAIC was the only source available to identify insurers operating in the individual and group markets until 2011. However, the NAIC data were quite limited until 2010, when major improvements occurred through the introduction of the SHCE. This new exhibit filed by all insurers allows for estimating participation of non-health insurers (e.g., life insurers) in health insurance markets and provides a break-down of the group market into small and large groups. We used the NAIC data from 2010-2012 to estimate the share of life insurers as well as changes in market structure (counts of insurers and $\mathrm{HHI}$ ) during this period.

The SHCE provides a unique opportunity to construct a complete picture of both the individual and small group health insurance markets starting with the 2010 filing year. Although we only have one "preACA” year (2010) for early implemented ACA provisions such as the MLR regulation, we can make some assessments of ACA effects. Despite the fact that MLR measurement from the SHCE does not exactly match CMS's measurement of MLR for rebates, the SHCE seems to perform well in predicting rebates. 
Table 1: Individual Market Coverage Information and Estimates by Survey, 2009

\begin{tabular}{|c|c|c|c|c|c|}
\hline & \multicolumn{2}{|c|}{ MEPS } & NHIS & CPS & ACS \\
\hline Survey Question(s) & \multicolumn{2}{|c|}{$\begin{array}{l}\text { Was anyone in the } \\
\text { family covered by } \\
\text { health insurance } \\
\text { from any source } \\
\text { listed on the card? }\end{array}$} & $\begin{array}{l}\text { Which kind of health } \\
\text { insurance or health care } \\
\text { coverage do you have? } \\
\text { Include those that pay } \\
\text { for only one type of } \\
\text { service (nursing home } \\
\text { care, accidents or dental } \\
\text { care). Exclude private } \\
\text { plans that provide extra } \\
\text { cash while } \\
\text { hospitalized). Which } \\
\text { one of these categories } \\
\text { best describes how this } \\
\text { plan was obtained? }\end{array}$ & $\begin{array}{l}\text { At any time } \\
\text { during 2009, } \\
\text { (was/were) } \\
\text { (you/ anyone in } \\
\text { this household) } \\
\text { covered by a } \\
\text { health insurance } \\
\text { plan that } \\
\text { (you/they) } \\
\text { PURCHASED } \\
\text { DIRECTLY } \\
\text { FROM AN } \\
\text { INSURANCE } \\
\text { COMPANY, } \\
\text { that is, not } \\
\text { related to } \\
\text { current or past } \\
\text { employment? }\end{array}$ & $\begin{array}{l}\text { Is this person } \\
\text { currently } \\
\text { covered by } \\
\text { any of the } \\
\text { following } \\
\text { types of } \\
\text { health } \\
\text { insurance or } \\
\text { coverage } \\
\text { plans? }\end{array}$ \\
\hline $\begin{array}{l}\text { Response Option Indicating Directly } \\
\text { Purchased or Individual Market } \\
\text { Coverage }\end{array}$ & \multicolumn{2}{|c|}{$\begin{array}{l}\text { (1) Directly from } \\
\text { an insurance agent; } \\
\text { (2) Directly from a } \\
\text { company; (3) } \\
\text { Directly from an } \\
\text { HMO }\end{array}$} & $\begin{array}{l}\text { (1)Through workplace } \\
\text { (self-employed or } \\
\text { professional } \\
\text { association) } \\
\text { (2) } \\
\text { Purchased directly } \\
\text { (3) Through school }{ }^{2}\end{array}$ & (1) Yes & $\begin{array}{l}\text { "Insurance } \\
\text { purchased } \\
\text { directly from } \\
\text { an insurance } \\
\text { company." }\end{array}$ \\
\hline Reference Period & \multicolumn{2}{|c|}{$\begin{array}{l}\text { Point-in-Time and } \\
\text { Monthly }\end{array}$} & Point-In-Time & $\begin{array}{l}\text { Any time } \\
\text { during year }\end{array}$ & $\begin{array}{l}\text { Point-In- } \\
\text { Time }\end{array}$ \\
\hline Recall Period of Item & \multicolumn{2}{|c|}{ None-6 months } & None & 4-16 months & None \\
\hline \multirow[t]{2}{*}{$\begin{array}{l}\text { Estimate of the Non-Elderly } \\
\text { Population, U.S. reporting Directly } \\
\text { Purchased insurance }\end{array}$} & $\begin{array}{l}\text { Point- } \\
\text { In- } \\
\text { Time }\end{array}$ & $\begin{array}{l}\text { Any } \\
\text { Time } \\
\text { During } \\
\text { Year } \\
\end{array}$ & Point-In-Time & $\begin{array}{l}\text { Any Time } \\
\text { During Year }\end{array}$ & $\begin{array}{l}\text { Point-In- } \\
\text { Time }\end{array}$ \\
\hline & $\begin{array}{l}9,550,4 \\
14 \\
\end{array}$ & \begin{tabular}{|l|}
$11,240,4$ \\
06 \\
\end{tabular} & $14,030,479$ & $18,454,383$ & $25,319,985$ \\
\hline $\begin{array}{l}\text { Estimate of the Non-Elderly } \\
\text { Population, U.S. reporting Directly } \\
\text { Purchased insurance adjusted for } \\
\text { Coverage Hierarchy }{ }^{1}\end{array}$ & $\begin{array}{l}8,215,3 \\
58 \\
\end{array}$ & & $13,379,765$ & $10,812,180$ & $16,635,033$ \\
\hline \multicolumn{6}{|c|}{$\begin{array}{l}\text { Source: Abraham J., Karaca-Mandic, P., Boudreaux M. “Sizing Up the Individual Market for Health Insurance: A } \\
\text { Comparison of Survey and Administrative Data Sources”, Medical Care Research and Review, 2013, Aug; 70(4): 418-33: } \\
\text { Tables 1, 2, and } 3 \text { (reproduced with authors' permission). }\end{array}$} \\
\hline
\end{tabular}


Table 2: Estimates of employees with health insurance coverage in firms with less than 50 employees

\begin{tabular}{|c|c|c|c|c|c|}
\hline & 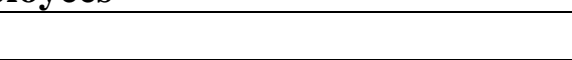 & 2009 & 2010 & 2011 & 2012 \\
\hline (1) & Total number of employees ${ }^{1}$ & $29,804,923$ & $29,792,468$ & $29,717,915$ & $30,615,432$ \\
\hline (2) & $\begin{array}{l}\% \text { of Employees in firms that offer } \\
\text { health insurance }\end{array}$ & 59.6 & 57.8 & 54.7 & 52.9 \\
\hline (3) & $\begin{array}{l}\text { \% of Employees enrolled in health } \\
\text { insurance in firms that offer health } \\
\text { insurance }^{3}\end{array}$ & 59.6 & 59.2 & 58.6 & 57.7 \\
\hline (4) & $\begin{array}{l}\% \text { of Enrollees that are enrolled in } \\
\text { self-insured plans in firms that } \\
\text { offer insurance }\end{array}$ & 11.6 & 12.5 & 10.8 & 12.5 \\
\hline (5) & $\begin{array}{l}\text { Total estimated number of } \\
\text { employees with health insurance } \\
\text { coverage }(1)^{*}(2)^{*}(3) / 10000\end{array}$ & $10,587,185$ & $10,194,268$ & $9,525,840$ & $9,344,840$ \\
\hline (6) & $\begin{array}{l}\text { Covered under self-insured } \\
\text { plans }\end{array}$ & $1,228,113$ & $1,274,284$ & $1,028,791$ & $1,168,105$ \\
\hline (7) & $\begin{array}{l}\text { Covered under non-self- } \\
\text { insured plans }\end{array}$ & $9,359,072$ & $8,919,984$ & $8,497,049$ & $8,176,735$ \\
\hline & & & & & \\
\hline & & & & & \\
\hline
\end{tabular}

1. Table I.B.1(2009) Number of private-sector employees by firm size and selected characteristics: United States, 2009 http://meps.ahrq.gov/mepsweb/data_stats/summ_tables/insr/national/series_1/2009/tib1.htm

2. Table I.B.2(2009) Percent of private-sector employees in establishments that offer health insurance by firm size and selected characteristics: United States, 2009

http://meps.ahrq.gov/mepsweb/data_stats/summ_tables/insr/national/series_1/2009/tib2.htm

3. Table I.B.2.b(2009) Percent of private-sector employees that are enrolled in health insurance at establishments that offer health insurance by firm size and selected characteristics: United States, 2009establishments that offer health insurance by firm size and selected characteristics: United States, 2009

http://meps.ahrq.gov/mepsweb/data_stats/summ_tables/insr/national/series_1/2009/tib2b.htm

4. Table I.B.2.b.(1)(2009) Percent of private-sector enrollees that are enrolled in self-insured plans at establishments that offer health insurance by firm size and selected characteristics: United States, 2009 http://meps.ahrq.gov/mepsweb/data_stats/summ_tables/insr/national/series_1/2009/tib2b1.htm 
Table 3: Number of insurers selling comprehensive health insurance in the individual market

\begin{tabular}{|c|c|c|c|c|c|c|c|c|}
\hline \multirow[b]{3}{*}{ State } & \multicolumn{4}{|c|}{2010} & \multicolumn{4}{|c|}{2012} \\
\hline & \multicolumn{2}{|c|}{ Health Insurer } & \multicolumn{2}{|c|}{ Life Insurer } & \multicolumn{2}{|c|}{ Health Insurer } & \multicolumn{2}{|c|}{ Life Insurer } \\
\hline & Credible & $\begin{array}{c}\text { Non- } \\
\text { Credible }\end{array}$ & Credible & $\begin{array}{c}\text { Non- } \\
\text { Credible }\end{array}$ & Credible & $\begin{array}{c}\text { Non- } \\
\text { Credible }\end{array}$ & Credible & $\begin{array}{c}\text { Non- } \\
\text { Credible }\end{array}$ \\
\hline AK & 1 & 1 & 4 & 9 & 2 & 0 & 4 & 8 \\
\hline$A L$ & 2 & 0 & 5 & 39 & 1 & 0 & 4 & 30 \\
\hline$A R$ & 3 & 2 & 4 & 38 & 2 & 3 & 4 & 28 \\
\hline$A Z$ & 4 & 4 & 14 & 29 & 3 & 2 & 18 & 16 \\
\hline CA & 1 & 0 & 10 & 39 & 1 & 1 & 11 & 24 \\
\hline $\mathrm{CO}$ & 3 & 7 & 15 & 33 & 3 & 6 & 16 & 18 \\
\hline CT & 3 & 3 & 4 & 25 & 3 & 4 & 7 & 14 \\
\hline $\mathrm{DC}$ & 3 & 2 & 1 & 19 & 3 & 4 & 2 & 18 \\
\hline $\mathrm{DE}$ & 1 & 3 & 2 & 22 & 2 & 2 & 3 & 15 \\
\hline $\mathrm{FL}$ & 9 & 6 & 17 & 48 & 12 & 3 & 19 & 22 \\
\hline GA & 5 & 4 & 15 & 40 & 6 & 4 & 16 & 22 \\
\hline $\mathrm{HI}$ & 2 & 0 & 0 & 12 & 2 & 0 & 0 & 9 \\
\hline IA & 2 & 3 & 5 & 32 & 2 & 3 & 6 & 23 \\
\hline ID & 3 & 0 & 5 & 23 & 3 & 2 & 3 & 15 \\
\hline IL & 4 & 6 & 18 & 34 & 3 & 9 & 19 & 19 \\
\hline IN & 2 & 5 & 14 & 34 & 3 & 4 & 16 & 18 \\
\hline KS & 2 & 4 & 7 & 30 & 2 & 4 & 9 & 23 \\
\hline KY & 2 & 4 & 2 & 31 & 2 & 3 & 3 & 23 \\
\hline LA & 5 & 1 & 8 & 33 & 5 & 1 & 7 & 24 \\
\hline $\mathrm{MA}$ & 6 & 6 & 1 & 32 & 7 & 5 & 2 & 21 \\
\hline$M D$ & 6 & 3 & 5 & 32 & 5 & 5 & 5 & 18 \\
\hline ME & 2 & 3 & 1 & 21 & 2 & 2 & 1 & 13 \\
\hline MI & 4 & 6 & 13 & 33 & 9 & 8 & 12 & 17 \\
\hline $\mathrm{MN}$ & 4 & 2 & 4 & 35 & 5 & 3 & 3 & 23 \\
\hline MO & 5 & 8 & 11 & 36 & 4 & 6 & 14 & 23 \\
\hline MS & 1 & 1 & 6 & 35 & 1 & 2 & 7 & 27 \\
\hline MT & 3 & 1 & 5 & 22 & 2 & 1 & 6 & 15 \\
\hline NC & 2 & 5 & 14 & 35 & 2 & 4 & 16 & 16 \\
\hline ND & 1 & 2 & 1 & 18 & 2 & 2 & 4 & 14 \\
\hline $\mathrm{NE}$ & 2 & 1 & 7 & 31 & 3 & 0 & 8 & 24 \\
\hline $\mathrm{NH}$ & 1 & 2 & 3 & 21 & 1 & 1 & 3 & 14 \\
\hline NJ & 7 & 2 & 0 & 29 & 7 & 2 & 2 & 18 \\
\hline NM & 3 & 0 & 3 & 37 & 2 & 0 & 5 & 24 \\
\hline NV & 2 & 5 & 8 & 31 & 3 & 3 & 8 & 19 \\
\hline NY & 14 & 4 & 2 & 34 & 12 & 3 & 5 & 16 \\
\hline $\mathrm{OH}$ & 5 & 11 & 10 & 39 & 5 & 11 & 13 & 25 \\
\hline OK & 2 & 3 & 8 & 34 & 1 & 4 & 10 & 23 \\
\hline OR & 7 & 3 & 2 & 30 & 7 & 2 & 2 & 20 \\
\hline PA & 14 & 4 & 11 & 36 & 18 & 7 & 12 & 20 \\
\hline
\end{tabular}




$\begin{array}{lrrrrrrrr}\text { RI } & 1 & 2 & 1 & 16 & 1 & 2 & 0 & 8 \\ \text { SC } & 3 & 2 & 9 & 42 & 4 & 1 & 10 & 24 \\ \text { SD } & 3 & 2 & 2 & 30 & 5 & 1 & 2 & 18 \\ \text { TN } & 2 & 4 & 9 & 39 & 3 & 4 & 12 & 26 \\ \text { TX } & 3 & 10 & 25 & 42 & 2 & 10 & 23 & 23 \\ \text { UT } & 3 & 1 & 7 & 30 & 3 & 1 & 5 & 17 \\ \text { VA } & 5 & 5 & 6 & 43 & 5 & 6 & 7 & 26 \\ \text { VT } & 2 & 1 & 0 & 10 & 2 & 1 & 0 & 12 \\ \text { WA } & 9 & 3 & 3 & 25 & 9 & 3 & 3 & 17 \\ \text { WI } & 9 & 6 & 10 & 30 & 9 & 6 & 13 & 21 \\ \text { WV } & 1 & 2 & 3 & 38 & 1 & 2 & 3 & 25 \\ \text { WY } & 1 & 2 & 4 & 24 & 1 & 2 & 7 & 17\end{array}$

U.S.

$\begin{array}{lllllllll}\text { Average } & 4 & 3 & 7 & 31 & 4 & 3 & 8 & 19\end{array}$

"Data Source: National Association of Insurance Commissioners, by permission. The NAIC does not endorse any analysis or conclusions based upon the use of its data."

Data from California is incomplete

Credible firms have at least 1,000 member-years. In 2012, "credible" status is defined by the aggregated member-years over 2011 and 2012 for insurers with < 75,000 member-years 
Table 4: Enrollment and market share by type of insurer in the individual market 2010

Health Insurer Life Insurer

2012

Health Insurer Life Insurer

\begin{tabular}{|c|c|c|c|c|c|c|c|c|c|c|}
\hline State & $\begin{array}{l}\text { Total } \\
\text { Member } \\
\text { Years, } \\
2010\end{array}$ & Credible & $\begin{array}{c}\text { Non- } \\
\text { Credible }\end{array}$ & Credible & $\begin{array}{c}\text { Non- } \\
\text { Credible }\end{array}$ & $\begin{array}{l}\text { Total } \\
\text { Member } \\
\text { Years, } 2012\end{array}$ & Credible & $\begin{array}{c}\text { Non- } \\
\text { Credible }\end{array}$ & Credible & $\begin{array}{c}\text { Non- } \\
\text { Credible }\end{array}$ \\
\hline AK & 16072 & 0.59 & 0.04 & 0.32 & 0.06 & 15004 & 0.67 & 0 & 0.27 & 0.05 \\
\hline$A L$ & 176526 & 0.87 & 0 & 0.1 & 0.02 & 167361 & 0.91 & 0 & 0.08 & 0.01 \\
\hline$A R$ & 118450 & 0.84 & 0 & 0.12 & 0.04 & 113218 & 0.85 & 0 & 0.12 & 0.02 \\
\hline$A Z$ & 255356 & 0.51 & 0 & 0.47 & 0.01 & 261828 & 0.51 & 0 & 0.48 & 0 \\
\hline CA & 986547 & 0.52 & 0 & 0.48 & 0 & 1095684 & 0.59 & 0 & 0.41 & 0 \\
\hline $\mathrm{CO}$ & 299793 & 0.46 & 0 & 0.53 & 0.01 & 268419 & 0.49 & 0 & 0.5 & 0.01 \\
\hline CT & 107938 & 0.6 & 0 & 0.37 & 0.03 & 111942 & 0.55 & 0.01 & 0.44 & 0.01 \\
\hline DC & 19524 & 0.8 & 0 & 0.09 & 0.11 & 18274 & 0.79 & 0 & 0.16 & 0.05 \\
\hline $\mathrm{DE}$ & 18496 & 0.5 & 0.01 & 0.33 & 0.16 & 17209 & 0.56 & 0 & 0.37 & 0.07 \\
\hline $\mathrm{FL}$ & 847542 & 0.71 & 0 & 0.28 & 0 & 835051 & 0.69 & 0 & 0.31 & 0 \\
\hline GA & 353740 & 0.69 & 0 & 0.29 & 0.01 & 382239 & 0.67 & 0 & 0.32 & 0 \\
\hline $\mathrm{HI}$ & 30913 & 0.99 & 0 & 0 & 0.01 & 28359 & 1 & 0 & 0 & 0 \\
\hline IA & 177363 & 0.86 & 0 & 0.11 & 0.03 & 177532 & 0.89 & 0.01 & 0.09 & 0.01 \\
\hline ID & 127000 & 0.77 & 0 & 0.22 & 0.01 & 99469 & 0.95 & 0 & 0.05 & 0 \\
\hline IL & 457366 & 0.7 & 0 & 0.29 & 0 & 145949 & 0.18 & 0 & 0.82 & 0 \\
\hline IN & 179663 & 0.62 & 0 & 0.35 & 0.03 & 174907 & 0.65 & 0 & 0.34 & 0 \\
\hline KS & 126792 & 0.28 & 0 & 0.69 & 0.04 & 120897 & 0.37 & 0 & 0.61 & 0.02 \\
\hline KY & 148638 & 0.94 & 0 & 0.04 & 0.02 & 133826 & 0.96 & 0 & 0.03 & 0.01 \\
\hline LA & 179178 & 0.86 & 0 & 0.12 & 0.02 & 170759 & 0.91 & 0 & 0.08 & 0.01 \\
\hline $\mathrm{MA}$ & 105980 & 0.95 & 0 & 0.02 & 0.03 & 81084 & 0.98 & 0 & 0 & 0.01 \\
\hline $\mathrm{MD}$ & 188040 & 0.78 & 0 & 0.22 & 0.01 & 179917 & 0.72 & 0 & 0.27 & 0.01 \\
\hline $\mathrm{ME}$ & 37236 & 0.63 & 0 & 0.34 & 0.02 & 33239 & 0.62 & 0 & 0.37 & 0.01 \\
\hline $\mathrm{MI}$ & 332637 & 0.6 & 0 & 0.37 & 0.02 & 323341 & 0.62 & 0 & 0.37 & 0 \\
\hline $\mathrm{MN}$ & 245068 & 0.87 & 0 & 0.12 & 0.01 & 247707 & 0.92 & 0 & 0.07 & 0.01 \\
\hline MO & 239103 & 0.62 & 0 & 0.35 & 0.02 & 245707 & 0.65 & 0 & 0.34 & 0.01 \\
\hline MS & 79547 & 0.54 & 0 & 0.38 & 0.08 & 79251 & 0.59 & 0 & 0.36 & 0.04 \\
\hline MT & 52903 & 0.58 & 0 & 0.4 & 0.02 & 50626 & 0.68 & 0 & 0.3 & 0.03 \\
\hline NC & 417102 & 0.85 & 0 & 0.14 & 0.01 & 430755 & 0.9 & 0 & 0.1 & 0 \\
\hline ND & 42441 & 0.81 & 0.03 & 0.12 & 0.05 & 43590 & 0.84 & 0.02 & 0.13 & 0.02 \\
\hline NE & 108392 & 0.67 & 0 & 0.29 & 0.04 & 121894 & 0.73 & 0 & 0.25 & 0.02 \\
\hline $\mathrm{NH}$ & 34484 & 0.67 & 0 & 0.27 & 0.06 & 35450 & 0.81 & 0 & 0.16 & 0.02 \\
\hline NJ & 122853 & 0.99 & 0 & 0 & 0.01 & 147306 & 0.98 & 0 & 0.01 & 0 \\
\hline NM & 61800 & 0.9 & 0 & 0.06 & 0.04 & 29822 & 0.84 & 0 & 0.11 & 0.05 \\
\hline NV & 87327 & 0.44 & 0.02 & 0.51 & 0.03 & 90886 & 0.46 & 0 & 0.53 & 0.01 \\
\hline NY & 129440 & 0.92 & 0.01 & 0.04 & 0.03 & 139101 & 0.93 & 0.01 & 0.05 & 0.01 \\
\hline $\mathrm{OH}$ & 202135 & 0.53 & 0.01 & 0.44 & 0.03 & 323139 & 0.75 & 0 & 0.24 & 0 \\
\hline OK & 120415 & 0.63 & 0 & 0.31 & 0.06 & 43093 & 0.11 & 0.02 & 0.83 & 0.04 \\
\hline OR & 185768 & 0.89 & 0.01 & 0.09 & 0.01 & 169248 & 0.92 & 0 & 0.07 & 0.01 \\
\hline
\end{tabular}




$\begin{array}{lrrrrrrrrrr}\text { PA } & 471105 & 0.77 & 0 & 0.22 & 0.01 & 444163 & 0.79 & 0 & 0.2 & 0 \\ \text { RI } & 30949 & 0.47 & 0.01 & 0.52 & 0 & 16495 & 0.95 & 0.01 & 0 & 0.04 \\ \text { SC } & 133799 & 0.58 & 0.01 & 0.35 & 0.06 & 126116 & 0.66 & 0 & 0.32 & 0.02 \\ \text { SD } & 59021 & 0.89 & 0.01 & 0.07 & 0.03 & 62808 & 0.96 & 0 & 0.02 & 0.02 \\ \text { TN } & 235107 & 0.68 & 0 & 0.28 & 0.03 & 238119 & 0.74 & 0 & 0.25 & 0.01 \\ \text { TX } & 734307 & 0.57 & 0 & 0.42 & 0.01 & 290110 & 0.02 & 0 & 0.97 & 0 \\ \text { UT } & 141189 & 0.68 & 0 & 0.31 & 0.01 & 136231 & 0.65 & 0 & 0.35 & 0.01 \\ \text { VA } & 317279 & 0.84 & 0 & 0.14 & 0.02 & 315664 & 0.87 & 0 & 0.12 & 0.01 \\ \text { VT } & 17516 & 0.99 & 0 & 0 & 0.01 & 18470 & 0.99 & 0 & 0 & 0.01 \\ \text { WA } & 315470 & 0.93 & 0 & 0.07 & 0 & 284273 & 0.98 & 0 & 0.02 & 0 \\ \text { WI } & 176491 & 0.55 & 0 & 0.42 & 0.03 & 172402 & 0.63 & 0.01 & 0.36 & 0 \\ \text { WV } & 22109 & 0.41 & 0.01 & 0.38 & 0.2 & 24017 & 0.62 & 0.01 & 0.29 & 0.08 \\ \text { WY } & 24423 & 0.42 & 0.01 & 0.37 & 0.2 & 22177 & 0.39 & 0.03 & 0.51 & 0.07 \\ \text { U.S. } & & & & & & & & & & 0.07 \\ \text { Total } & 10098333 & & & & & 9304128 & & & 0.26 & 0.02 \\ \text { U.S. Average } & & 0.7 & 0 & 0.26 & 0.04 & & 0.72 & 0 & 0.26\end{array}$

"Data Source: National Association of Insurance Commissioners, by permission. The NAIC does not endorse any analysis or conclusions based upon the use of its data."

Data from California is incomplete

Credible firms have at least 1,000 member-years. In 2012, "credible" status is defined by the aggregated member-years over 2011 and 2012 for insurers with < 75,000 member-years 
Table 5: Number of insurers selling comprehensive health insurance in the small group

market

\begin{tabular}{|c|c|c|c|c|c|c|c|c|}
\hline \multirow[b]{3}{*}{ State } & \multicolumn{4}{|c|}{2010} & \multicolumn{4}{|c|}{2012} \\
\hline & \multicolumn{2}{|c|}{ Health Insurer } & \multicolumn{2}{|c|}{ Life Insurer } & \multicolumn{2}{|c|}{ Health Insurer } & \multicolumn{2}{|c|}{ Life Insurer } \\
\hline & Credible & $\begin{array}{c}\text { Non- } \\
\text { Credible }\end{array}$ & Credible & $\begin{array}{c}\text { Non- } \\
\text { Credible }\end{array}$ & Credible & $\begin{array}{c}\text { Non- } \\
\text { Credible }\end{array}$ & Credible & $\begin{array}{c}\text { Non- } \\
\text { Credible }\end{array}$ \\
\hline AK & 2 & 0 & 2 & 5 & 2 & 0 & 4 & 1 \\
\hline $\mathrm{AL}$ & 2 & 1 & 1 & 8 & 2 & 1 & 1 & 7 \\
\hline$A R$ & 5 & 2 & 2 & 11 & 7 & 0 & 1 & 9 \\
\hline$A Z$ & 8 & 3 & 9 & 12 & 6 & 1 & 8 & 9 \\
\hline$C A$ & 2 & 0 & 7 & 9 & 2 & 0 & 6 & 7 \\
\hline $\mathrm{CO}$ & 8 & 3 & 3 & 9 & 7 & 1 & 3 & 6 \\
\hline CT & 8 & 0 & 4 & 6 & 6 & 0 & 2 & 6 \\
\hline DC & 6 & 4 & 3 & 5 & 6 & 5 & 3 & 2 \\
\hline $\mathrm{DE}$ & 4 & 5 & 1 & 6 & 4 & 5 & 1 & 5 \\
\hline $\mathrm{FL}$ & 13 & 1 & 3 & 8 & 13 & 4 & 4 & 3 \\
\hline GA & 12 & 0 & 11 & 10 & 13 & 1 & 11 & 7 \\
\hline $\mathrm{HI}$ & 5 & 0 & 0 & 1 & 5 & 0 & 0 & 1 \\
\hline IA & 7 & 4 & 2 & 9 & 8 & 2 & 1 & 7 \\
\hline ID & 4 & 1 & 0 & 7 & 4 & 1 & 1 & 5 \\
\hline IL & 12 & 6 & 12 & 13 & 10 & 4 & 9 & 11 \\
\hline IN & 6 & 5 & 12 & 12 & 7 & 4 & 14 & 7 \\
\hline KS & 4 & 3 & 7 & 9 & 4 & 4 & 7 & 6 \\
\hline KY & 4 & 4 & 1 & 9 & 6 & 1 & 1 & 7 \\
\hline LA & 5 & 2 & 2 & 7 & 6 & 1 & 3 & 6 \\
\hline $\mathrm{MA}$ & 12 & 2 & 3 & 6 & 12 & 2 & 3 & 7 \\
\hline$M D$ & 11 & 2 & 2 & 2 & 12 & 1 & 2 & 4 \\
\hline $\mathrm{ME}$ & 4 & 0 & 2 & 4 & 4 & 0 & 2 & 2 \\
\hline $\mathrm{MI}$ & 8 & 2 & 13 & 11 & 17 & 0 & 11 & 4 \\
\hline $\mathrm{MN}$ & 7 & 1 & 0 & 5 & 8 & 1 & 0 & 4 \\
\hline MO & 10 & 5 & 7 & 12 & 7 & 5 & 7 & 7 \\
\hline $\mathrm{MS}$ & 1 & 2 & 4 & 7 & 3 & 0 & 4 & 5 \\
\hline MT & 3 & 0 & 2 & 7 & 3 & 0 & 3 & 5 \\
\hline NC & 6 & 1 & 4 & 11 & 6 & 1 & 5 & 7 \\
\hline ND & 3 & 2 & 1 & 3 & 3 & 2 & 1 & 2 \\
\hline NE & 3 & 0 & 6 & 10 & 3 & 1 & 4 & 9 \\
\hline $\mathrm{NH}$ & 5 & 2 & 2 & 4 & 5 & 0 & 0 & 4 \\
\hline NJ & 9 & 1 & 3 & 3 & 8 & 1 & 3 & 2 \\
\hline NM & 5 & 1 & 3 & 8 & 4 & 1 & 1 & 3 \\
\hline NV & 10 & 2 & 6 & 11 & 8 & 2 & 6 & 7 \\
\hline NY & 22 & 2 & 2 & 5 & 19 & 1 & 4 & 2 \\
\hline $\mathrm{OH}$ & 17 & 4 & 6 & 18 & 16 & 2 & 9 & 13 \\
\hline OK & 6 & 1 & 8 & 8 & 4 & 2 & 6 & 7 \\
\hline
\end{tabular}




$\begin{array}{lrrrrrrrr}\text { OR } & 7 & 3 & 1 & 1 & 7 & 2 & 1 & 0 \\ \text { PA } & 20 & 4 & 5 & 10 & 20 & 2 & 5 & 7 \\ \text { RI } & 2 & 2 & 1 & 2 & 2 & 2 & 1 & 2 \\ \text { SC } & 5 & 1 & 5 & 11 & 4 & 3 & 3 & 8 \\ \text { SD } & 5 & 0 & 0 & 6 & 6 & 0 & 0 & 5 \\ \text { TN } & 7 & 4 & 5 & 12 & 5 & 2 & 6 & 6 \\ \text { TX } & 10 & 3 & 14 & 15 & 10 & 3 & 13 & 8 \\ \text { UT } & 4 & 1 & 4 & 8 & 3 & 1 & 8 & 4 \\ \text { VA } & 15 & 5 & 4 & 11 & 17 & 1 & 4 & 6 \\ \text { VT } & 4 & 0 & 1 & 1 & 3 & 1 & 1 & 0 \\ \text { WA } & 8 & 4 & 2 & 5 & 11 & 1 & 4 & 3 \\ \text { WI } & 20 & 2 & 8 & 7 & 21 & 0 & 8 & 5 \\ \text { WV } & 5 & 2 & 3 & 10 & 5 & 1 & 3 & 9 \\ \text { WY } & 2 & 1 & 3 & 4 & 2 & 1 & 4 & 1\end{array}$

U.S.

$\begin{array}{lllllllll}\text { Average } & 7 & 2 & 4 & 8 & 7 & 2 & 4 & 5\end{array}$

"Data Source: National Association of Insurance Commissioners, by permission. The NAIC does not endorse any analysis or conclusions based upon the use of its data."

Data from California is incomplete

Credible firms have at least 1,000 member-years. In 2012, "credible" status is defined by the aggregated member-years over 2011 and 2012 for insurers with < 75,000 member-years 
Table 6: Enrollment and market share by type of insurer in the small group market

\begin{tabular}{|c|c|c|c|c|c|c|c|c|c|c|}
\hline & & & 201 & & & & & & & \\
\hline & & Health & Insurer & Life I & iurer & & Health & nsurer & Life II & urer \\
\hline State & $\begin{array}{l}\text { Total } \\
\text { Member } \\
\text { Years, } \\
2010\end{array}$ & Cred. & Non-Cred. & Cred. & $\begin{array}{l}\text { Non- } \\
\text { Cred. }\end{array}$ & $\begin{array}{l}\text { Total } \\
\text { Member } \\
\text { Years, } \\
2012\end{array}$ & Cred. & $\begin{array}{l}\text { Non- } \\
\text { Cred. }\end{array}$ & Cred. & $\begin{array}{l}\text { Non- } \\
\text { Cred. }\end{array}$ \\
\hline AK & 27193 & 0.81 & 0 & 0.13 & 0.06 & 32982 & 0.75 & 0 & 0.25 & 0 \\
\hline$A L$ & 333464 & 0.96 & 0 & 0.03 & 0.01 & 300824 & 0.98 & 0 & 0.02 & 0 \\
\hline AR & 128104 & 0.73 & 0 & 0.25 & 0.02 & 135260 & 0.83 & 0 & 0.16 & 0.01 \\
\hline$A Z$ & 310048 & 0.41 & 0 & 0.58 & 0.01 & 224005 & 0.35 & 0 & 0.64 & 0.01 \\
\hline CA & 737370 & 0.39 & 0 & 0.61 & 0 & 714052 & 0.38 & 0 & 0.62 & 0 \\
\hline $\mathrm{CO}$ & 296943 & 0.59 & 0 & 0.4 & 0 & 234853 & 0.6 & 0 & 0.39 & 0.01 \\
\hline CT & 303407 & 0.96 & 0 & 0.04 & 0.01 & 246543 & 0.98 & 0 & 0.01 & 0 \\
\hline DC & 125154 & 0.89 & 0.01 & 0.09 & 0 & 97986 & 0.88 & 0.01 & 0.1 & 0 \\
\hline $\mathrm{DE}$ & 55031 & 0.91 & 0.03 & 0.04 & 0.02 & 54266 & 0.97 & 0.01 & 0.01 & 0.01 \\
\hline $\mathrm{FL}$ & 873558 & 0.66 & 0 & 0.34 & 0 & 823504 & 0.74 & 0 & 0.25 & 0 \\
\hline GA & 529174 & 0.77 & 0 & 0.23 & 0 & 610714 & 0.78 & 0 & 0.22 & 0 \\
\hline $\mathrm{HI}$ & 191901 & 1 & 0 & 0 & 0 & 168746 & 1 & 0 & 0 & 0 \\
\hline IA & 204892 & 0.88 & 0.01 & 0.11 & 0.01 & 164182 & 0.9 & 0 & 0.08 & 0.01 \\
\hline ID & 99273 & 0.97 & 0 & 0 & 0.02 & 85064 & 0.98 & 0 & 0.01 & 0.01 \\
\hline IL & 733237 & 0.75 & 0 & 0.24 & 0 & 260338 & 0.53 & 0 & 0.47 & 0.01 \\
\hline IN & 293311 & 0.66 & 0 & 0.32 & 0.01 & 334529 & 0.74 & 0 & 0.26 & 0.01 \\
\hline KS & 240971 & 0.19 & 0 & 0.8 & 0.01 & 194569 & 0.25 & 0 & 0.74 & 0 \\
\hline KY & 184178 & 0.96 & 0.01 & 0.02 & 0.01 & 183265 & 1 & 0 & 0 & 0 \\
\hline LA & 327749 & 0.89 & 0 & 0.1 & 0.01 & 287175 & 0.92 & 0 & 0.08 & 0 \\
\hline MA & 679117 & 0.96 & 0 & 0.04 & 0 & 581971 & 0.98 & 0 & 0.02 & 0 \\
\hline MD & 426090 & 0.92 & 0 & 0.08 & 0 & 353976 & 0.93 & 0 & 0.07 & 0 \\
\hline $\mathrm{ME}$ & 93656 & 0.61 & 0 & 0.39 & 0 & 81686 & 0.72 & 0 & 0.28 & 0 \\
\hline $\mathrm{MI}$ & 499867 & 0.7 & 0 & 0.29 & 0.01 & 654179 & 0.9 & 0 & 0.1 & 0 \\
\hline $\mathrm{MN}$ & 272651 & 1 & 0 & 0 & 0 & 316387 & 1 & 0 & 0 & 0 \\
\hline MO & 399047 & 0.7 & 0 & 0.29 & 0.01 & 322929 & 0.78 & 0 & 0.22 & 0 \\
\hline MS & 128627 & 0.8 & 0.01 & 0.18 & 0.01 & 117300 & 0.9 & 0 & 0.09 & 0.01 \\
\hline MT & 57293 & 0.84 & 0 & 0.12 & 0.04 & 51845 & 0.88 & 0 & 0.11 & 0.01 \\
\hline NC & 440594 & 0.77 & 0 & 0.22 & 0.01 & 350545 & 0.81 & 0 & 0.18 & 0 \\
\hline ND & 82930 & 0.98 & 0 & 0.01 & 0 & 67569 & 0.98 & 0 & 0.01 & 0.01 \\
\hline NE & 96726 & 0.66 & 0 & 0.31 & 0.03 & 88153 & 0.8 & 0 & 0.19 & 0.01 \\
\hline $\mathrm{NH}$ & 107310 & 0.97 & 0 & 0.02 & 0.01 & 87754 & 0.99 & 0 & 0 & 0.01 \\
\hline NJ & 873581 & 0.98 & 0 & 0.02 & 0 & 711940 & 0.98 & 0 & 0.01 & 0 \\
\hline NM & 81586 & 0.82 & 0 & 0.17 & 0 & 40989 & 0.85 & 0 & 0.15 & 0 \\
\hline NV & 128670 & 0.68 & 0.01 & 0.3 & 0.01 & $\begin{array}{l}105508 \\
144482\end{array}$ & 0.65 & 0.01 & 0.34 & 0.01 \\
\hline NY & 1785384 & 0.97 & 0 & 0.02 & 0 & 0 & 0.94 & 0 & 0.06 & 0 \\
\hline $\mathrm{OH}$ & 842523 & 0.9 & 0 & 0.1 & 0 & 955972 & 0.86 & 0 & 0.13 & 0 \\
\hline OK & 202981 & 0.61 & 0 & 0.38 & 0.01 & 80669 & 0.38 & 0 & 0.61 & 0.01 \\
\hline
\end{tabular}




$\begin{array}{lrrrrrrrrrr}\text { OR } & 234594 & 0.93 & 0 & 0.07 & 0 & 228449 & 0.94 & 0 & 0.06 & 0 \\ \text { PA } & 1110624 & 0.94 & 0 & 0.06 & 0 & 6 & 0.98 & 0 & 0.02 & 0 \\ \text { RI } & 101552 & 0.75 & 0.01 & 0.23 & 0.01 & 85611 & 0.77 & 0.01 & 0.22 & 0 \\ \text { SC } & 195703 & 0.85 & 0 & 0.14 & 0.01 & 158375 & 0.9 & 0 & 0.09 & 0.01 \\ \text { SD } & 57999 & 0.99 & 0 & 0 & 0.01 & 52654 & 0.99 & 0 & 0 & 0.01 \\ \text { TN } & 427090 & 0.82 & 0.01 & 0.17 & 0.01 & 353371 & 0.82 & 0 & 0.18 & 0 \\ \text { TX } & 1197943 & 0.53 & 0 & 0.47 & 0 & 757686 & 0.25 & 0 & 0.75 & 0 \\ \text { UT } & 213549 & 0.75 & 0 & 0.24 & 0.01 & 244766 & 0.77 & 0 & 0.23 & 0 \\ \text { VA } & 536232 & 0.91 & 0 & 0.08 & 0.01 & 465807 & 0.91 & 0 & 0.09 & 0 \\ \text { VT } & 66264 & 0.62 & 0 & 0.38 & 0 & 60698 & 1 & 0 & 0 & 0 \\ \text { WA } & 236052 & 0.8 & 0.01 & 0.2 & 0 & 275131 & 0.84 & 0 & 0.16 & 0 \\ \text { WI } & 368754 & 0.5 & 0 & 0.49 & 0 & 407307 & 0.58 & 0 & 0.42 & 0 \\ \text { WV } & 72228 & 0.87 & 0 & 0.09 & 0.03 & 70902 & 0.96 & 0 & 0.03 & 0.01 \\ \text { WY } & 25910 & 0.64 & 0.02 & 0.32 & 0.03 & 24148 & 0.62 & 0.01 & 0.34 & 0.02 \\ \text { U.S. } & & & & & & & & & & \\ \text { Total } & 18038085 & & & & & 15814790 & & & & \\ \text { U.S. Average } & 0.79 & 0 & 0.2 & 0.01 & & 0.81 & 0 & 0.19 & 0\end{array}$

"Data Source: National Association of Insurance Commissioners, by permission. The NAIC does not endorse any analysis or conclusions based upon the use of its data."

Data from California is incomplete

Cred: Credible.

Credible firms have at least 1,000 member-years. In 2012, "credible" status is defined by the aggregated member-years over 2011 and 2012 for insurers with < 75,000 member-years 
Table 7: Entry and Exit of Insurers 2010-2012

\begin{tabular}{|c|c|c|c|c|c|c|c|c|}
\hline & \multicolumn{4}{|c|}{ Comprehensive Individual Market } & \multicolumn{4}{|c|}{ Small Group Market } \\
\hline & Credible 2012 & $\begin{array}{c}\text { Not } \\
\text { Credible } \\
2012 \\
\end{array}$ & $\begin{array}{c}\text { Not } \\
\text { Present } \\
2012 \\
\end{array}$ & Total & $\begin{array}{l}\text { Credible } \\
2012\end{array}$ & $\begin{array}{c}\text { Not } \\
\text { Credible } \\
2012 \\
\end{array}$ & $\begin{array}{c}\text { Not } \\
\text { Present } \\
2012 \\
\end{array}$ & Total \\
\hline \multicolumn{9}{|l|}{ Present in 2010, Credible } \\
\hline $\begin{array}{l}\text { Credible in } \\
2011\end{array}$ & 437 & 0 & 18 & 455 & 470 & 0 & 35 & 505 \\
\hline $\begin{array}{l}\text { Not Credible in } \\
2011\end{array}$ & 37 & 11 & 9 & 57 & 21 & 12 & 12 & 45 \\
\hline $\begin{array}{l}\text { Not Present in } \\
2011\end{array}$ & 1 & 2 & 19 & 22 & 0 & 0 & 35 & 35 \\
\hline Total & 475 & 13 & 46 & 534 & 491 & 12 & 82 & 585 \\
\hline \multicolumn{9}{|l|}{$\begin{array}{l}\text { Present in 2010, Not- } \\
\text { Credible }\end{array}$} \\
\hline $\begin{array}{l}\text { Credible in } \\
2011\end{array}$ & 32 & 0 & 2 & 34 & 24 & 0 & 0 & 24 \\
\hline $\begin{array}{l}\text { Not Credible in } \\
2011\end{array}$ & 51 & 815 & 291 & 1157 & 40 & 274 & 62 & 376 \\
\hline $\begin{array}{l}\text { Not Present in } \\
2011\end{array}$ & 0 & 41 & 495 & 536 & 0 & 7 & 93 & 100 \\
\hline Total & 83 & 856 & 788 & 1727 & 64 & 281 & 155 & 500 \\
\hline Entered in 2011, Credible & 11 & 8 & 19 & 38 & 12 & 0 & 1 & 13 \\
\hline $\begin{array}{l}\text { Entered in 2011, Not- } \\
\text { Credible }\end{array}$ & 13 & 160 & 104 & 277 & 12 & 27 & 16 & 55 \\
\hline Entered in 2012 & 3 & 129 & 0 & 132 & 9 & 27 & 0 & 36 \\
\hline
\end{tabular}

Credible firms have at least 1,000 member-years. In 2012, "credible" status is defined by the aggregated member-years over 2011 and 2012 for insurers with < 75,000 member-years 
Figure 1: Herfindahl-Hirschman Index (HHI) for the Individual Market, 2010

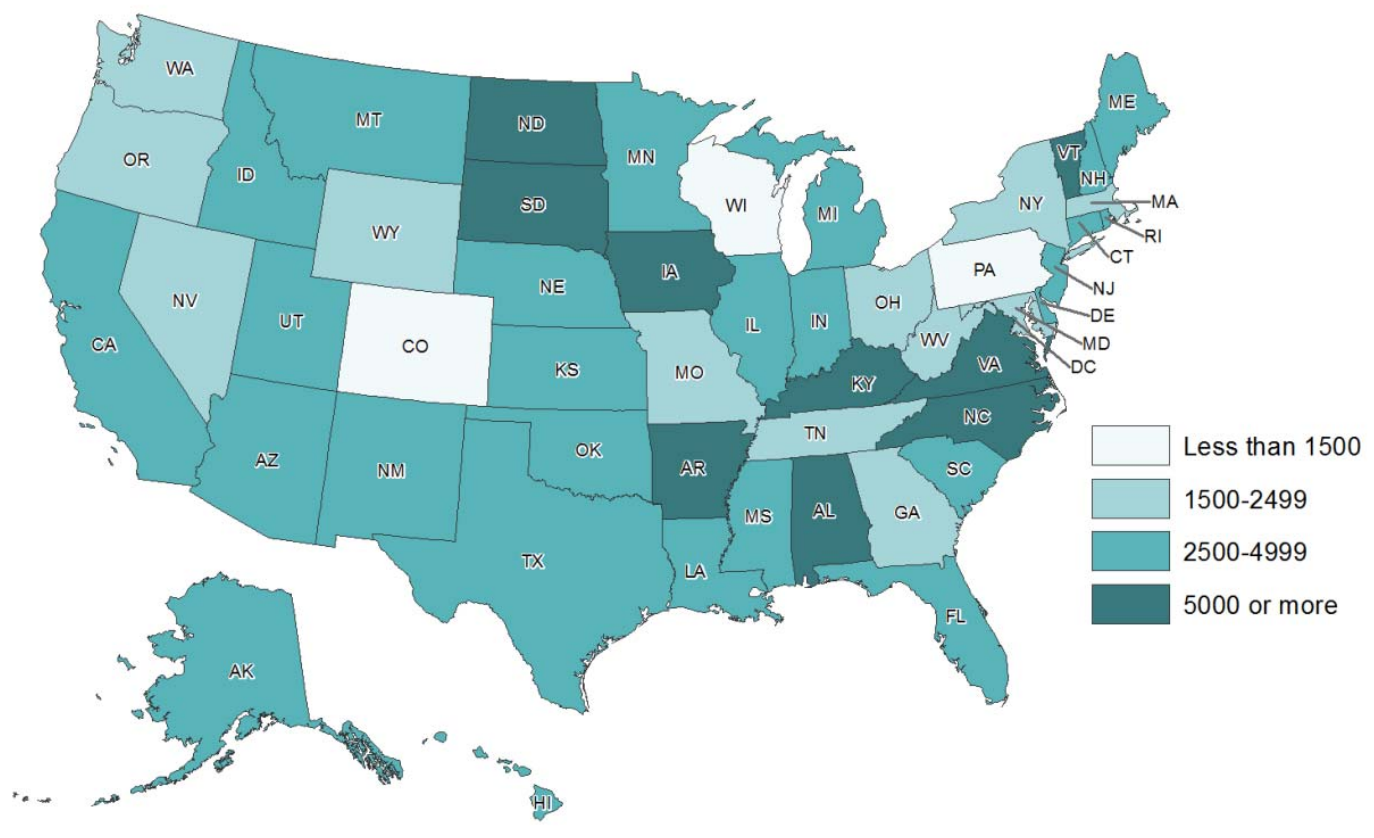

Figure 2: Herfindahl-Hirschman Index (HHI) for the Individual Market, 2012

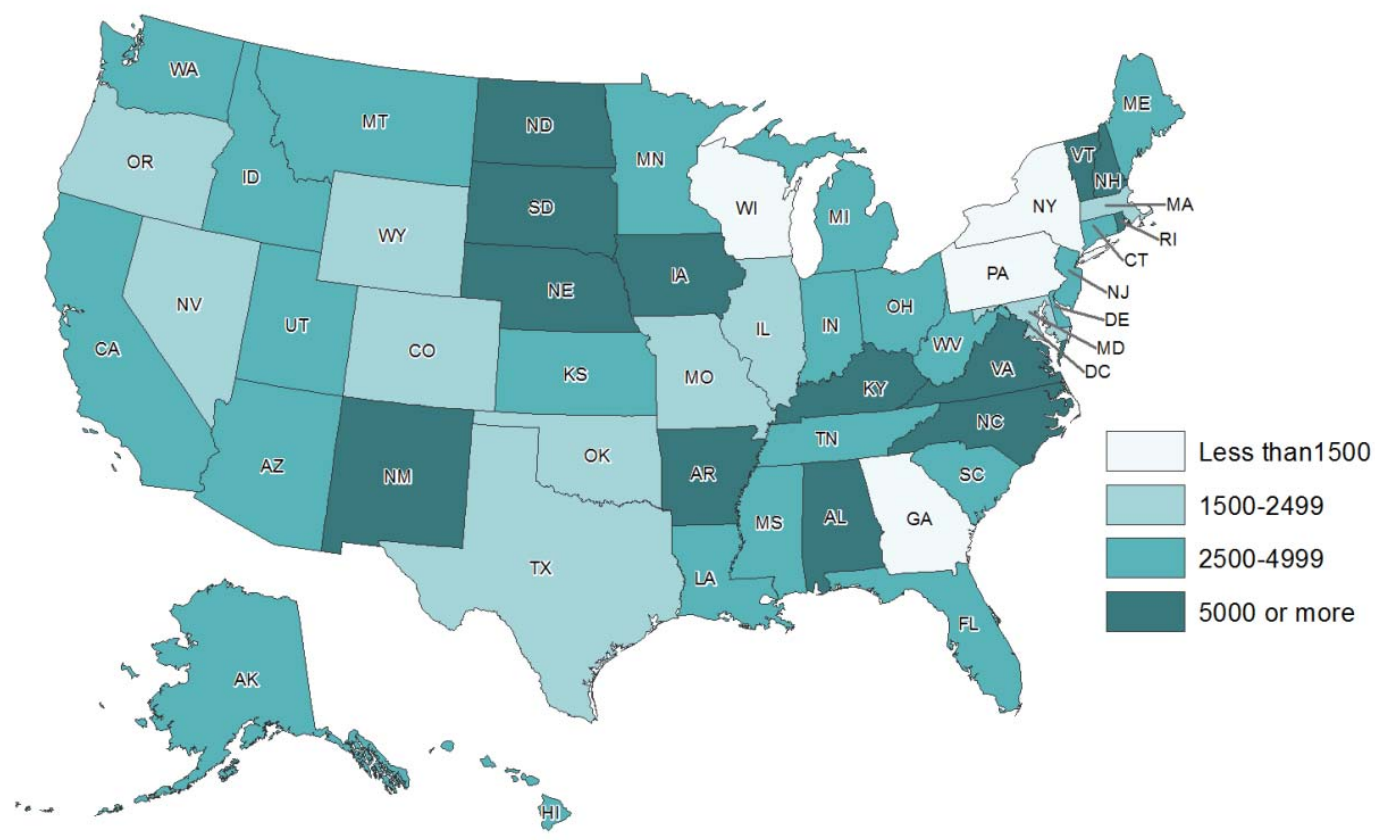


Figure 3: Herfindahl-Hirschman Index (HHI) for the Small Group Market, 2010

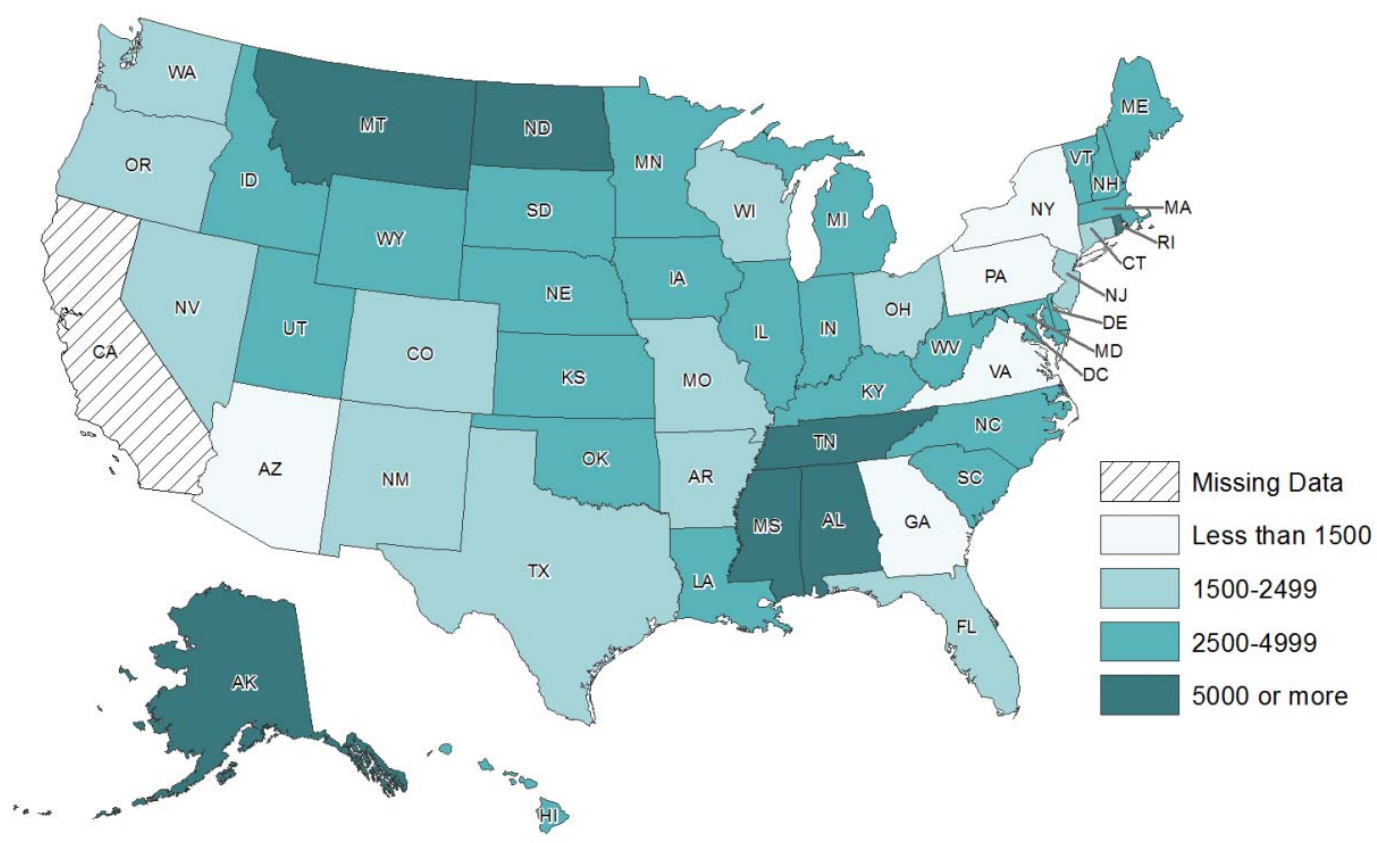

Figure 4: Herfindahl-Hirschman Index (HHI) for the Small Group Market, 2012

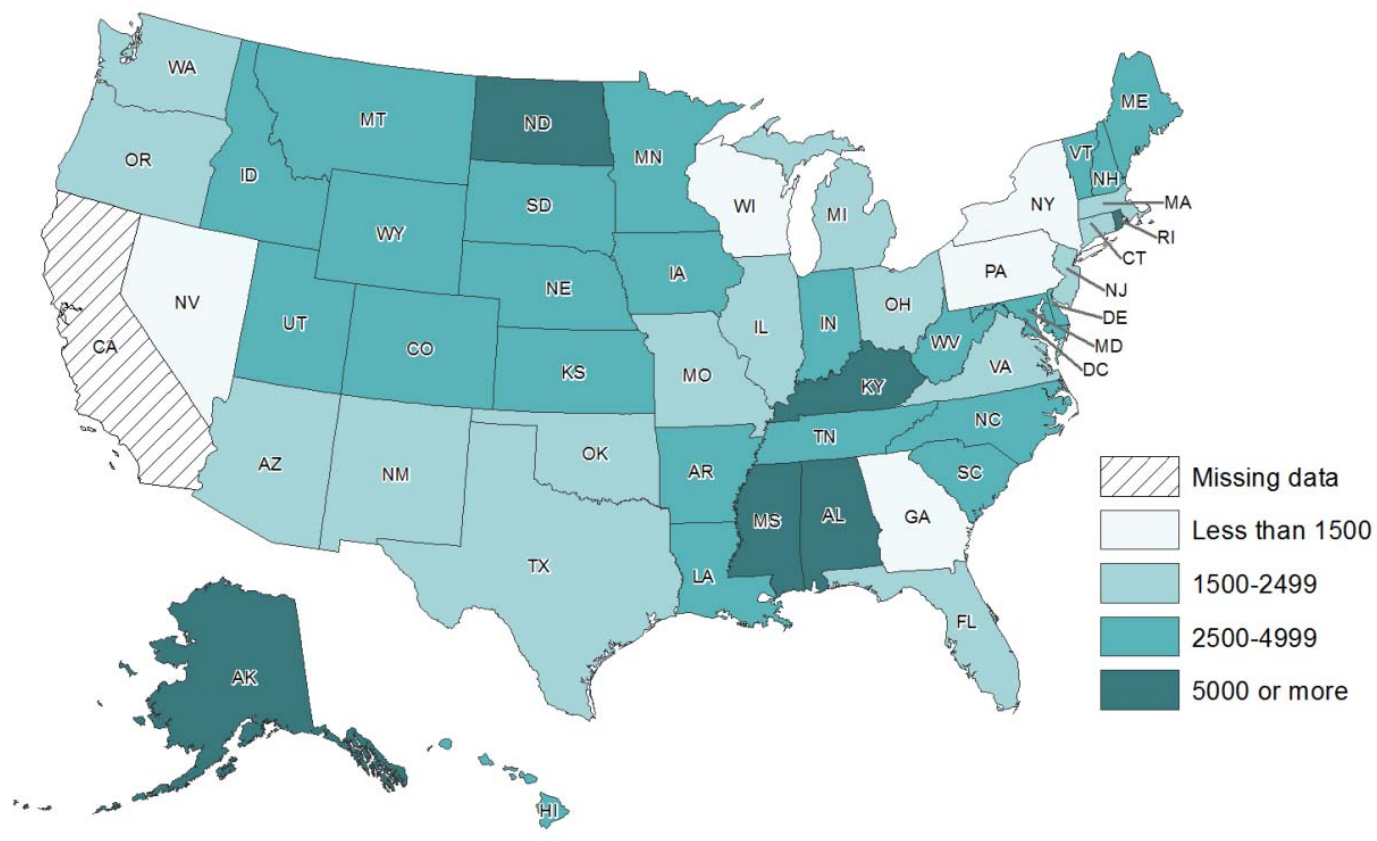


Figure 5: Premiums and Claims in the Individual Market, $\$$ (inflated to 2012)

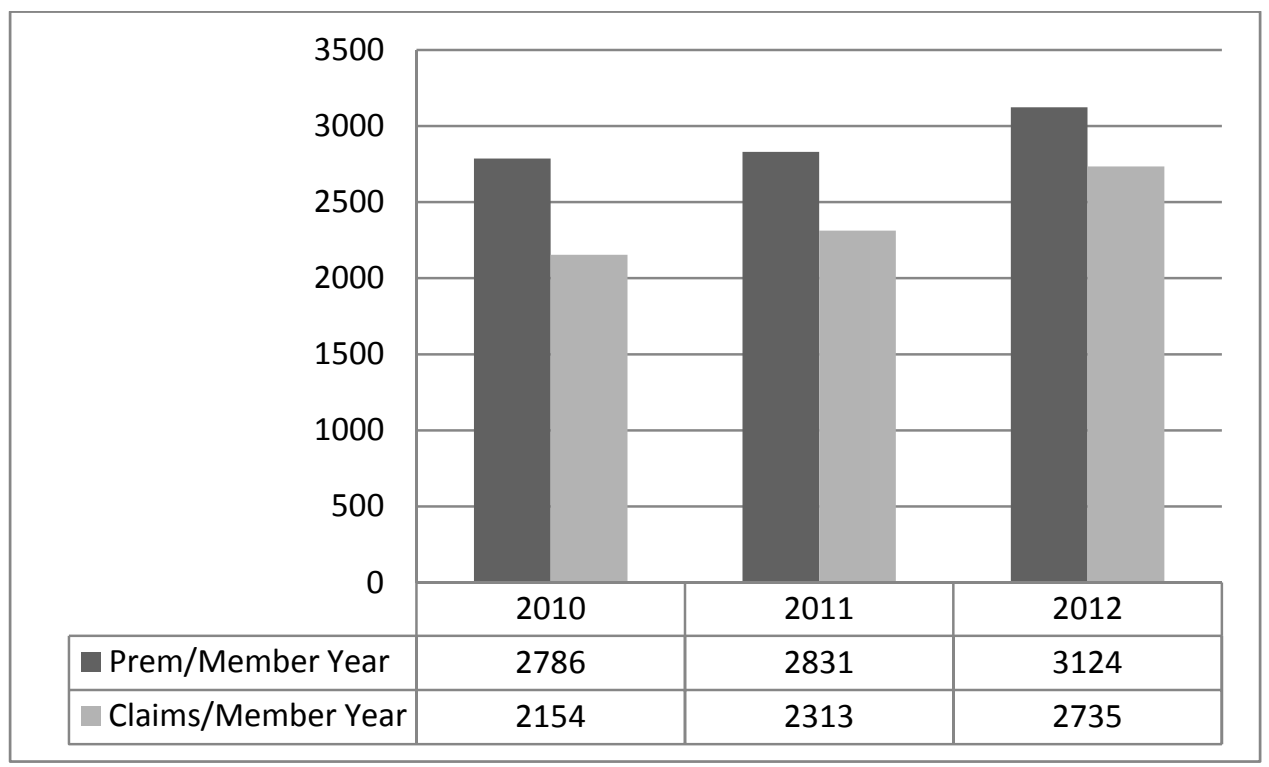

Note: All dollar amounts are inflated to 2012 dollars.

Figure 6: Premiums and Claims in the Small group Market, $\$$ (inflated to 2012)

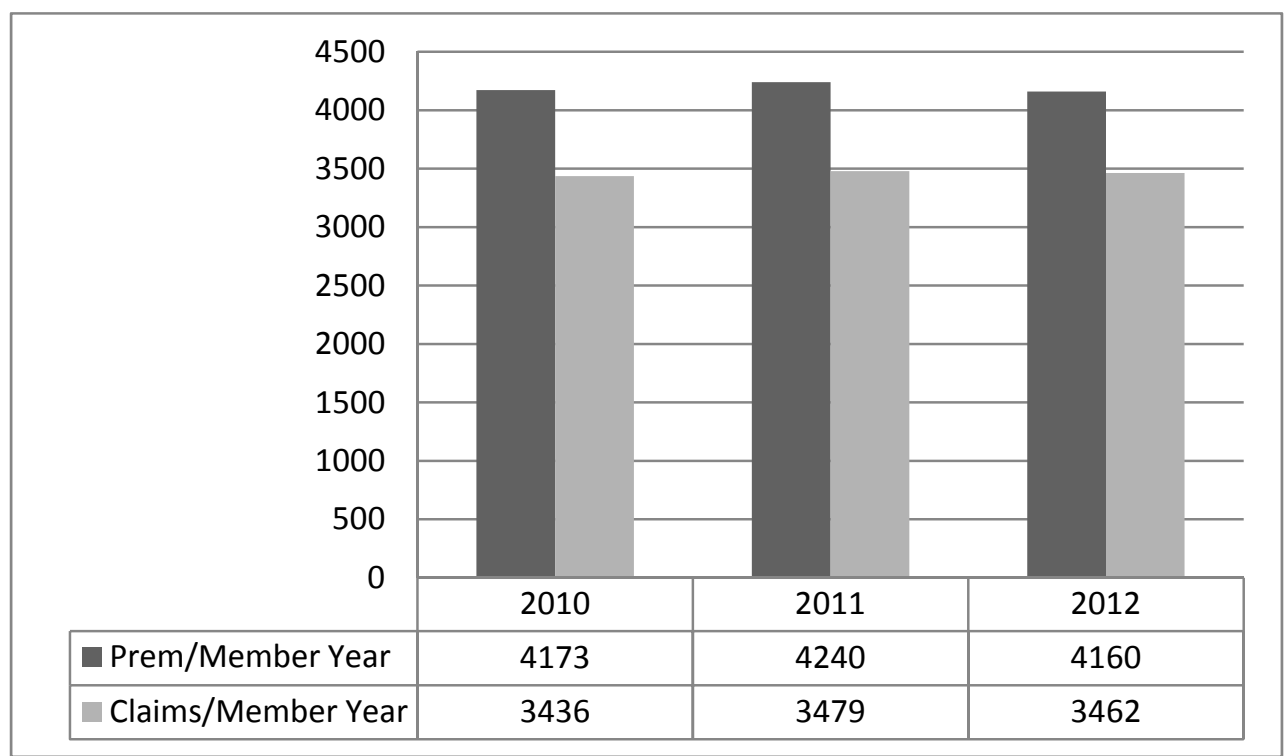

All dollar amounts are inflated to 2012 dollars. 
Figure 7: Distribution of Premiums, Individual Market

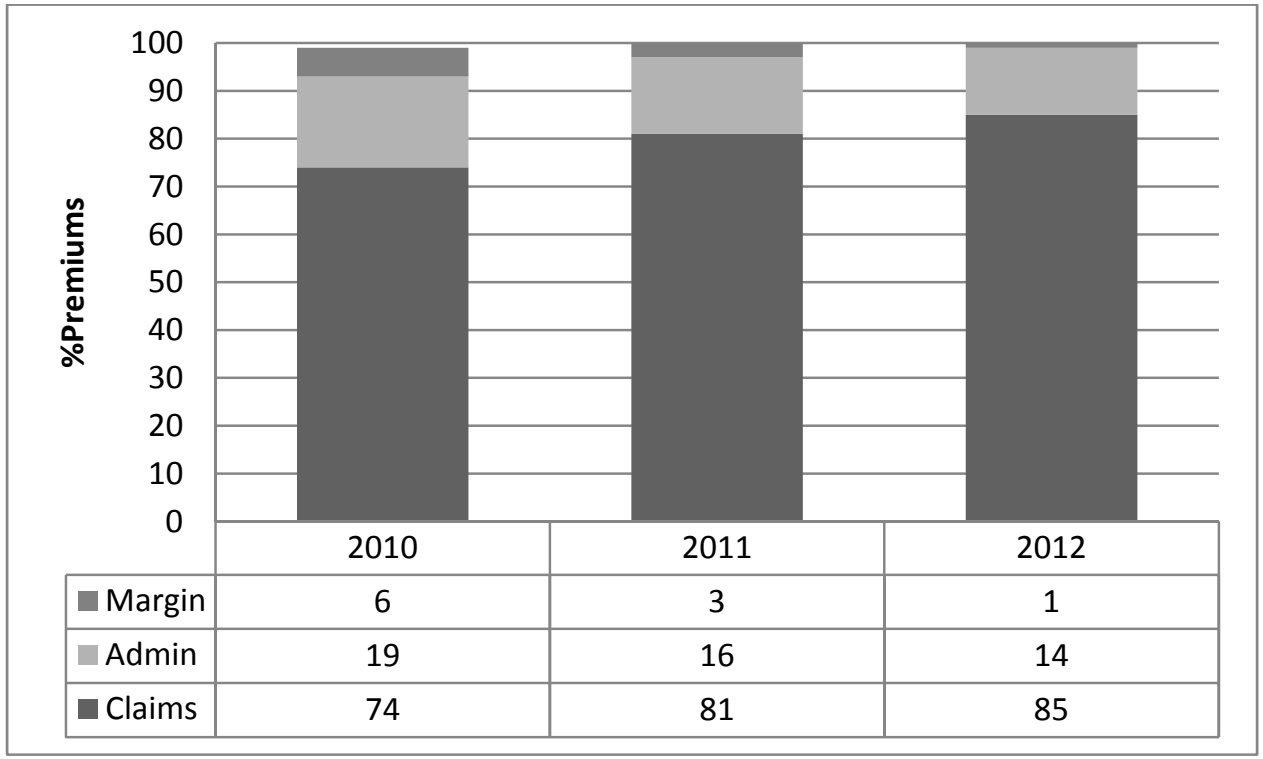

Note: Claims include spending for other clinical services, quality improvement activities and spending for detection of fraud

Figure 8: Distribution of Premiums, Small Group Market

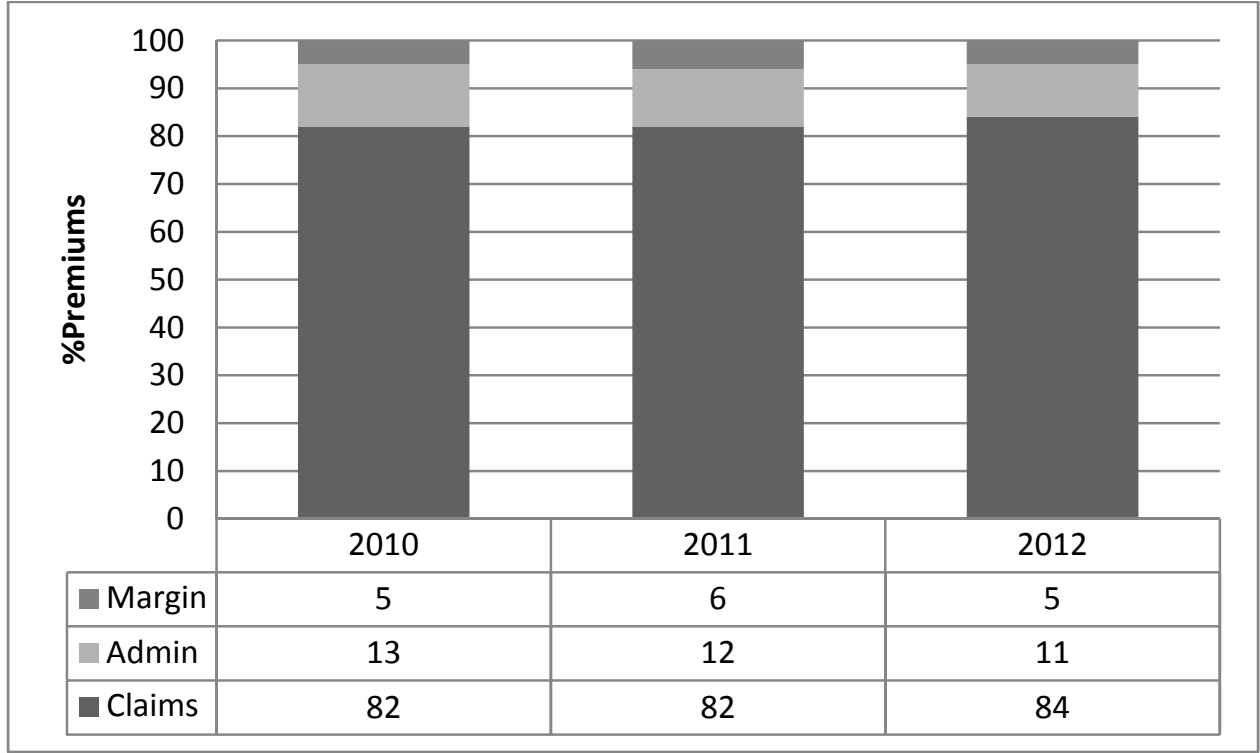

Note: Claims include spending for other clinical services, quality improvement activities and spending for detection of fraud 
Table 8: Medical Loss Ratios, 2010-2012, Fully Credible Insurers (at least 75,000 member years)

\begin{tabular}{l|ccc|ccc|} 
& \multicolumn{3}{|c}{ Individual Market } & \multicolumn{3}{c|}{ Small Group Market } \\
\cline { 2 - 7 } & 2010 & 2011 & 2012 & 2010 & 2011 & 2012 \\
\hline Unique Number of Insurers & 27 & 30 & 28 & 56 & 57 & 53 \\
Number of Insurer-State Obs. & 28 & 31 & 28 & 64 & 64 & 57 \\
& & & & & & \\
Percent Met MLR Threshold & & & & & & \\
$(\%)$ & 46 & 77 & 89 & 73 & 80 \\
\hline MLR & & & & & & 84.88 \\
Mean & 80.39 & 83.64 & 85.38 & 83.56 & 83.34 & $(83.70-$ \\
& $(76.76-$ & $(81.59-$ & $(83.21-$ & $(82.06-$ & $(82.22-$ & $86.06)$ \\
(95\% Cl) & $84.03)$ & $85.69)$ & $87.54)$ & $85.05)$ & $84.47)$ & 83.7 \\
Median & 79.3 & 81.8 & 83.55 & 82.7 & 83.25 & \multicolumn{3}{c}{} \\
\hline
\end{tabular}


Table 9: Medical Loss Ratios, 2010-2012, Partially Credible Insurers (at least 1,000 member years, but less than 75,000 member years)

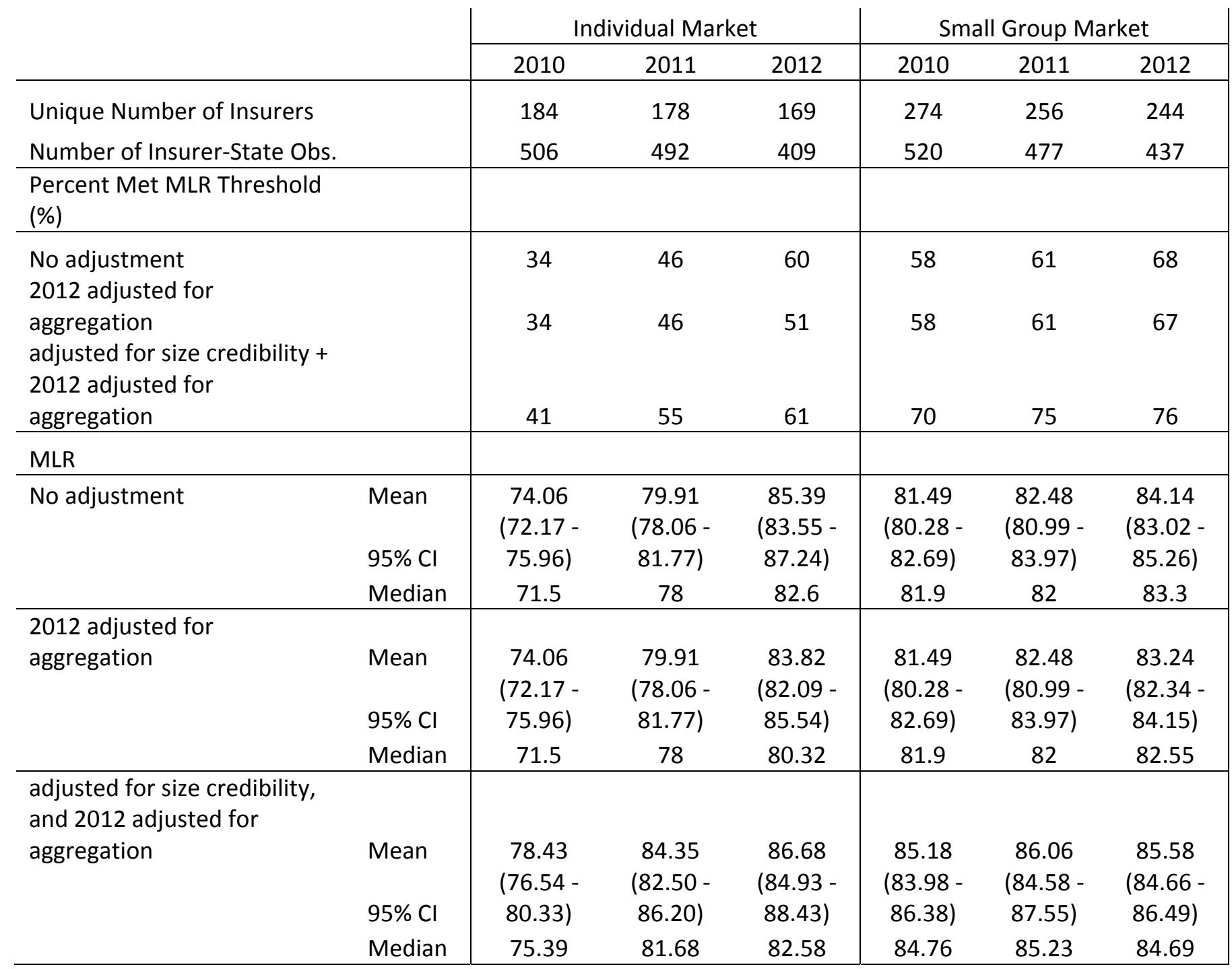




\section{REFERENCES}

Abraham JM, DeLeire T, Royalty AB. Access to health insurance at small establishments: What can we learn from analyzing other fringe benefits? Inquiry 2009;46(3):253-273.

Abraham JM, Karaca-Mandic P. Regulating the medical loss ratio: Implications for the individual market. American Journal of Managed Care 2011;17(3):211-224.

Abraham JM, Karaca-Mandic P. The performance of private health insurers in the commercial market. In: T. Culyer, ed., Encyclopedia of Health Economics, eds. Tony Culyer, Waltham, MA: Elsevier.

Forthcoming, 2013.

Abraham JM, Karaca-Mandic P, Boudreaux M. Sizing up the individual market for health insurance: A comparison of survey and administrative data sources. Medical Care Research and Review 2013; 70(4):418-433.

Abraham JM, Karaca-Mandic P, Simon K. How has the Affordable Care Act's medical loss ratio regulation affected insurer behavior? Minneapolis, MN: University of Minnesota Working Paper, 2013.

Buchmueller, T., and J. DiNardo. Did Community Rating Induce an Adverse Selection Death Spiral? Evidence From New York, Pennsylvania, and Connecticut, American Economic Review, 2002, 92(1): 280-294.

Cantor JC, Monheit AC, Brownlee S, Schneider C. The adequacy of household survey data for evaluating the nongroup health insurance market. Health Services Research 2007;42(4):1739-1757.

Congressional Budget Office. Updated estimates for the insurance coverage provisions of the affordable care act. Washington, DC: CBO, March 2012.

Cox C, Claxton G, Levitt L. Beyond rebates: How much are consumers saving from the ACA's medical loss ratio provision? Kaiser Family Foundation, June 6, 2013. Available at: http://kff.org/healthreform/perspective/beyond-rebates-how-much-are-consumers-saving-from-the-acas-medical-loss-ratioprovision/

Davidoff, A., L. Blumberg, and L. Nichols. State Health Insurance Market Reforms and Access to Insurance for High-Risk Employees, Journal of Health Economics,2005, 24: 725-750.

Department of Health and Human Services. Health insurance issuers implementing medical loss ratio (MLR) requirements under the Patient Protection and Affordable Care Act. Federal Register 2010;75(230):74864-74934. Available at: http://www.gpo.gov/fdsys/pkg/FR-2010-12-01/pdf/201029596.pdf. (Accessed September 30, 2013.)

Government Accountability Office. Private health insurance: Early indicators show that most insurers would have met or exceeded new medical loss ratio standards. GAO-12-90R, October 31, 2011. Available at: http://www.gao.gov/products/GAO-12-90R. (Accessed September 30, 2013.)

Hall MA, McCue MJ. Estimating the impact of the medical loss ratio rule: A state-by-state analysis. New York, NY: The Commonwealth Fund, April 2012.

http://kff.org/health-reform/perspective/beyond-rebates-how-much-are-consumers-saving-from-the-acasmedical-loss-ratio-provision/. (Accessed September 30, 2013.) 
Kaiser Family Foundation. Rate review: Spotlight on state efforts to make health insurance more affordable. Executive Summary. December 2010. Available at:

http://kaiserfamilyfoundation.files.wordpress.com/2013/01/8122.pdf. (Accessed October 1, 2013.)

Karaca-Mandic P, Abraham J. Using data from the National Association of Insurance Commissioners for health reform evaluation. State Health Reform Assistance Issue Brief. Princeton, NJ: The Robert Wood Johnson Foundation, July 2013

Karaca-Mandic P, Abraham J, Phelps C. How do health insurance loading fees vary by group size?: Implications for healthcare reform. International Journal of Health Care Finance and Economics 2011;11(3):181-207.

Karaca-Mandic P, Abraham J, Simon K. Is the medical loss ratio a good target measure for regulation in the individual market for health insurance? Health Economics. Forthcoming 2013.

Karaca-Mandic P, Feldman R, Graven P. The role of agents and brokers in the market for health insurance. Working Paper \#19342. Cambridge, MA: National Bureau of Economic Research, 2013.

Klerman JA, Davern M, Call KT, Lynch V, Ringel, J. Understanding the current population survey's insurance estimates and the Medicaid 'undercount'. Health Affairs 2009;28(6):w991-w1001.

Mach A, O’Hara B. Do people really have multiple health insurance plans? Estimates of nongroup health insurance in the American community survey. SEHSD. Working Paper Number 2011-28, 2011. Available at: http://www.census.gov/hhes/www/hlthins/publications/Multiple_Coverage.pdf. (Accessed July 2011.)

Marquis, M. S., and S. Long. Effects of “Second Generation” Small Group Health Insurance Market Reforms, 1993 to 1997, Inquiry, 2002, 38: 365-380.

McCue MJ, Hall MA. Insurers' responses to regulation of medical loss ratios. New York, NY: The Commonwealth Fund, December 2012.

McCue MJ, Hall M, Liu X. Impact of medical loss regulation on the financial performance of health insurers. Health Affairs 2013;32(9):1546-1551.

Monheit A, Schone BS. How has small group market reform affected employee health insurance coverage? Journal of Public Economics 2004;88(1-2):237-254.

Phelps, C. (2010). Health economics. Reading, MA: Addison-Wesley.

Simon, K. Adverse Selection in Health Insurance Markets? Evidence From State Small-Group Health Insurance Reforms, Journal of Public Economics, 2005, 89: 1865-1877 